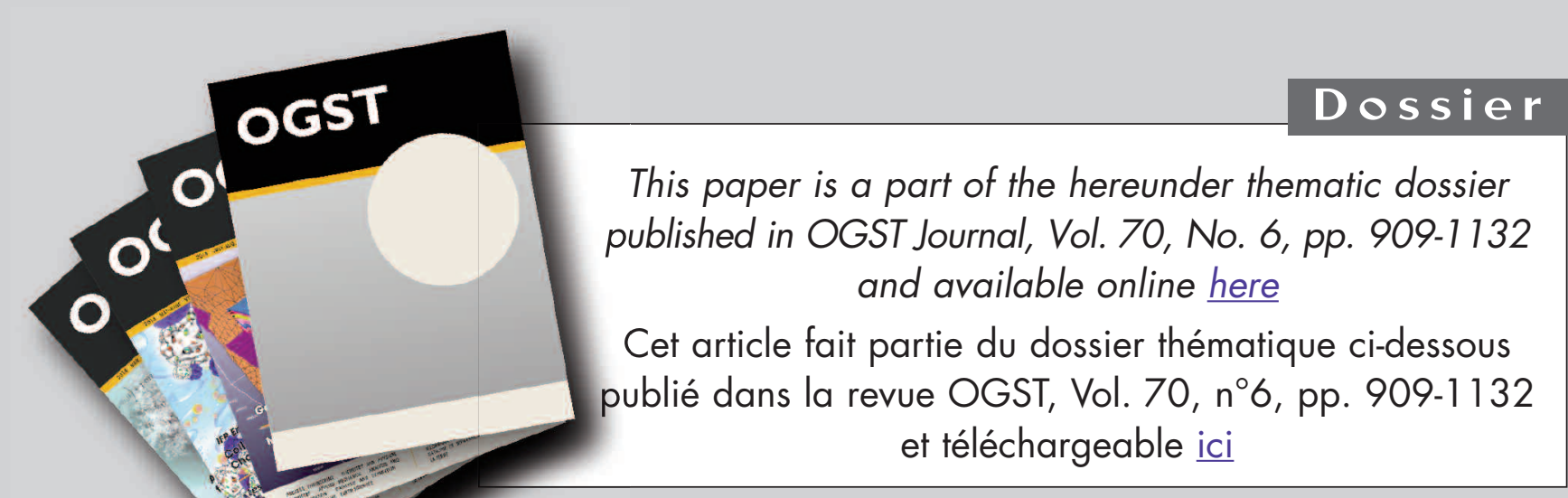

Oil \& Gas Science and Technology - Rev. IFP Energies nouvelles, Vol. 70 (2015), No. 6, pp. 909-1132

Copyright (C) 2015, IFP Energies nouvelles

909 > Editorial - Enhanced Oil Recovery (EOR), Asphaltenes and Hydrates Éditorial - EOR «récupération assistée du pétrole», Asphaltènes et Hydrates D. Langevin and F. Baudin

\section{ENHANCED OIL RECOVERY (EOR)}

917 > HP-HT Drilling Mud Based on Environmently-Friendly Fluorinated Chemicals Boues de forage HP/HT à base de composés fluorés respectueux de I'environnement

I. Henaut, D. Pasquier, S. Rovinetti and B. Espagne

931 > Effective Viscosity in Porous Media and Applicable Limitations for Polymer Flooding of an Associative Polymer

Viscosité effective dans des médias poreux et limites d'application de l'injection de polymères associatifs

P. Zhang, Y. Wang, Y. Yang, W. Chen and S. Bai

$941>$ Dynamic Gelation of HPAM/Cr(III) under Shear in an Agitator and Porous Media Gélification dynamique de HPAM/Cr(III) sous cisaillement dans un agitateur et en milieu poreux

Y. Haiyang, W. Yefei, Z. Jian, L. Peng and S. Shenglong

$951>$ Computer Modeling of the Displacement Behavior of Carbon Dioxide in Undersaturated Oil Reservoirs

Modélisation par ordinateur du comportement de déplacement du dioxyde de carbone dans des réservoirs d'huile non saturés

B. Ju, Y.S. Wu and J. Qin

$967>$ Predicting CO, Minimum Miscibility Pressure (MMP) Using Alternating Conditional Expectation (ACE) Algorithm

Prédiction de la pression miscibilité minimum (MMP) du CO en utilisant un algorithme basé sur l'ACE (Alternating Conditional Expectation)

0 . Alomair, A. Malallah, A. Elsharkawy and M. Iqbal

983 > Towards the Development of Bitumen Carbonates: An Integrated Analysis of Grosmont Steam Pilots

Vers le développement des carbonates bitumineux : une analyse intégrée des pilotes vapeur de Grosmont

C.C. Ezeuko, J. Wang, M.S. Kallos and I.D. Gates

1007> A Novel Model of Foam Flooding Considering Multi-Factors for Enhancing Oil Recovery

Un nouveau modèle d'injection de mousse considérant de multiples facteurs afin d'améliorer la récupération de pétrole

J. Wang, H. Liu, H. Zhang, G. Zhang, P. Liu and K. Sepehrnoori
1025> Testing of Snorre Field Foam Assisted Water Alternating Gas (FAWAG) Performance in New Foam Screening Model

Vérification des performances de la méthode FAWAG (Foam Assisted Water Alternating Gas) sur le champ de Snorre, en Norvège, avec un nouveau modèle de sélection des mousses

P. Spirov and S. Rudyk

\section{ASPHALTENES}

1035> Structural Study of Asphaltenes from Iranian Heavy Crude Oil Étude structurale d'asphaltènes de pétrole brut lourd iranien L. Davarpanah, F. Vahabzadeh and A. Dermanaki

$1051>$ Experimental Study and Mathematical Modeling of Asphaltene Deposition Mechanism in Core Samples

Étude expérimentale et modélisation mathématique du mécanisme de déposition d'asphaltène dans des carottes de forage

T. Jafari Behbahani, C. Ghotbi, V. Taghikhani and A. Shahrabadi

1075> Prediction of the Gas Injection Effect on the Asphaltene Phase Envelope Prévision Prévision de l'effet d'injection de gaz sur l'enveloppe de phase des asphaltènes P. Bahrami, R. Kharrat, S. Mahdavi and H. Firoozinia

\section{HYDRATES}

1087> Methane Hydrate Formation and Dissociation in the Presence of Silica Sand and Bentonite Clay

Formation et dissociation d'hydrates de méthane en présence de sable de silice et d'argile de bentonite

V. Kumar Saw, G. Udayabhanu, A. Mandal and S. Laik

$1101>$ Prediction of Mass Flow Rate in Supersonic Natural Gas Processing Prédiction du débit massique dans les applications de traitement supersonique du gaz naturel

C. Wen, X. Cao, Y. Yang and Y. Feng

$1111>$ Experimental Study on Hydrate Induction Time of Gas-Saturated Water-in-Oil Emulsion using a High-Pressure Flow Loop

Étude expérimentale sur le temps d'induction d'hydrate d'une émulsion eau-enhuile saturée en gaz en utilisant une boucle à circulation sous haute pression X.F. Lv, B.H. Shi, Y. Wang, Y.X. Tang, L.Y. Wang and J. Gong

1125> Hollow Silica: A Novel Material for Methane Storage La silice creuse : un nouveau matériau pour le stockage de méthane V.D. Chari, P.S.R. Prasad and S.R. Murthy 


\title{
Towards the Development of Bitumen Carbonates: An Integrated Analysis of Grosmont Steam Pilots
}

\author{
C.C. Ezeuko*, J. Wang, M.S. Kallos and I.D. Gates \\ Department of Chemical and Petroleum Engineering, Schulich School of Engineering, University of Calgary - Canada \\ e-mail: cezeuko@ucalgary.ca - jwang@ucalgary.ca -mskallos@ucalgary.ca - idgates@ucalgary.ca \\ * Corresponding author
}

\begin{abstract}
Résumé - Vers le développement des carbonates bitumineux : une analyse intégrée des pilotes vapeur de Grosmont - La Formation de Grosmont de l'Alberta, au Canada, est un réservoir de carbonates riches en bitume, hautement fracturé, karstifié et vacuolaire, situé à l'ouest et en-dessous du gisement de sables bitumineux de l'Athabasca. La plate-forme de carbonates bitumineux s'étend sur environ $500 \mathrm{~km}$ en longueur et jusqu'à $150 \mathrm{~km}$ en largeur et contient un volume de pétrole estimé à 64,5 milliards de $\mathrm{m}^{3}$ (406,5 milliards de barils). La Formation de Grosmont est plus vaste que le total cumulé de tous les autres dépôts de carbonates bitumineux connus au monde. Dans le cas présent, nous analysons les premiers pilotes vapeur de Grosmont afin d'améliorer la conception des futurs pilotes ainsi que le développement commercial de cet imposant dépôt de bitume. En accord avec les conclusions des analyses précédentes de ces pilotes de Grosmont, ceux-ci étaient raisonnablement satisfaisants compte tenu de la nature hétérogène de la Formation de Grosmont. Des facteurs opérationnels tels qu'une qualité médiocre de la vapeur, des pressions d'injection élevées non optimisées et des problèmes de réalisation semblent avoir lourdement affecté les performances de récupération. À l'évidence, les opérations de récupération à base de vapeur détiennent un potentiel intéressant pour Grosmont, en particulier étant donné qu'il s'agit d'une technologie commerciale maîtrisée. Suivant une analyse intégrée des premiers pilotes de Grosmont, nous pouvons affirmer que la stimulation cyclique à la vapeur (Cyclic Steam Stimulation, CSS) au moyen de puits horizontaux présente un potentiel supérieur pour le développement des carbonates de Grosmont par rapport à la technologie de drainage gravitaire assisté par injection de vapeur (Steam-Assisted Gravity Drainage, SAGD).
\end{abstract}

\begin{abstract}
Towards the Development of Bitumen Carbonates: An Integrated Analysis of Grosmont Steam Pilots - The Grosmont Formation in Alberta, Canada is a highly fractured, karstified and vuggy bitumen-rich carbonate reservoir located west of and below the Athabasca oil sands deposit. The bitumen carbonate platform extends about $500 \mathrm{~km}$ in length and up to $150 \mathrm{~km}$ in width and contains an estimated 64.5 billion $\mathrm{m}^{3}$ (406.5 billion barrels) of oil. The Grosmont Formation is larger than the combined total of all other known carbonate bitumen deposits in the world. Here, we analyze early Grosmont steam pilots to improve the design of future pilots and commercial development of this massive bitumen deposit. In agreement with the conclusions of earlier analysis of these Grosmont pilots, they were reasonably successful considering the heterogeneous nature of the Grosmont Formation. Operational factors such as poor steam quality, non-optimized high injection pressures and completion issues appear to have heavily impacted recovery performances. Clearly, steam-based recovery operations have good potential for Grosmont, especially considering that it
\end{abstract}


is mature commercial technology. Following an integrated analysis of early Grosmont pilots, we posit that Cyclic Steam Stimulation (CSS) using horizontal wells exhibits greater potential for the development of Grosmont carbonate, compared with Steam-Assisted Gravity Drainage technology (SAGD).

\section{INTRODUCTION}

The Grosmont Formation is a highly fractured, karstified and vuggy bitumen-rich carbonate located West of the Athabasca oil sands deposit in Alberta, Canada. The bitumen carbonate platform in Northern Alberta is a massive resource which extends about $500 \mathrm{~km}$ in length and up to $150 \mathrm{~km}$ in width and is often referred to as the carbonate triangle. With an original bitumen in-place estimated to be as high as 64.5 billion $\mathrm{m}^{3}$ (406.5 billion barrels) (ERCB, 2011), the Grosmont Formation is larger than the combined total of all other known carbonate bitumen deposits in the world and represents an immense economic potential for the province of Alberta and Canada in general.

Aggressive development of Grosmont is expected within the next decade, championed by Laricina Energy Ltd. However, two other energy giants, Royal Dutch Shell plc and Husky Energy, are also primed to develop their large mineral rights within Grosmont. Primary conventional oil recovery is driven by natural (in situ) energy, typically a combination of oil expansion, gas ex-solution and expansion, formation compaction and aquifer expansion. Unfortunately, heavy oil and bitumen have minimal dissolved gas and large viscosity contrast with formation water resulting in typically poor or essentially zero primary recovery. An example is the primary recovery of less than $1 \%$ of the original oil-inplace reported for the Ikiztepe heavy oil reservoir in Turkey (Nakamura et al., 1995). A major additional challenge associated with bitumen recovery from carbonates is the often extreme complexity of carbonate geology. A common tendency is for heavy oil carbonate reservoirs to be oil-wetted, making traditional secondary recovery such as water injection equally inefficient due to excessive channeling and early breakthrough. Grosmont bitumen fluid characterization indicates that viscosity in reservoir conditions is in excess of 1 million $\mathrm{cP}\left({ }^{\circ} \mathrm{API}\right.$ 5-9) and a reasonable lateral and vertical viscosity heterogeneity/variation exists (Zhao and Machel, 2012). Steam-based thermal processes which have successfully been used to exploit Athabasca bitumen offer a viable option for decreasing in situ viscosity, thereby mobilizing Grosmont bitumen.

Steam processes that have been field-tested in carbonates include Thermally-Assisted Gas-Oil Gravity Drainage (TA-GOGD) (Macaulay et al., 1995); Cyclic Steam
Stimulation (CSS) (Jiang et al., 2010; Samir, 2010; Yuan et al., 2010; Novak et al., 2007; Zhou et al., 1998; Ahmad and Milhem, 1989, Milhem and Ahmad, 1987) and steamflooding (Courderc et al., 1990; Sahuquet et al., 1990; Sahuquet and Ferrier, 1982). Also, heavy oil carbonate pilots involving Steam-Assisted Gravity Drainage (SAGD) and solvent variants of SAGD are underway at Grosmont. For a steam-based process to be successful in heavy oil carbonate, it must increase the in situ oil mobility while simultaneously providing or exploring sufficient drive energy for moving mobile oil to production wells. A number of processes have been identified as responsible (to varying degrees) for several successful applications of steam-based recovery from heavy oil carbonates. These include; free and forced imbibition (enhanced by thermal wettability reversal from oil to water-wet) of steam condensate into the matrix and attendant displacement of oil from the matrix into fracture networks, viscosity reduction of heavy oil both due to the thermal effect and dissolution of $\mathrm{CO}_{2}$ into oil, gravity drainage of oil, an internal depletion drive associated with steam flashing, thermal oil expansion and forced oil displacement (Mollaei and Maini, 2010; Babadagli and Al-Bemani, 2007; Briggs et al., 1992; Hjelmeland and Larrondo, 1986; Dreher et al., 1986).

In view of the complex geology of Grosmont, a key challenge is to maximize the transfer of injected heat to the bitumen by minimizing in situ heat losses associated with an insufficiently characterized network of vugs, fractures and caverns. Even when the bitumen viscosity has been reduced to a reasonable value $(<200 \mathrm{cP})$, drive energy is critical to deliver heated bitumen to production wells. Regardless of the steam-based method used in previous carbonate pilots TA-GOGD (Yates field, Qarn Alarn) (Snell and Close, 1999; Macaulay et al., 1995), CSS (Grosmont, Issaran, Ikiztepe, Oude-Shiranish, Wafra) (Jiang et al., 2010; Samir, 2010; Yuan et al., 2010; Novak et al., 2007; Zhou et al., 1998; Ahmad and Milhem, 1989, Milhem and Ahmad, 1987), steamflooding (Emeraude, Grosmont, Lacq Supérieur, Wafra, Ikiztepe) (Brown et al., 2011; Courderc et al., 1990; Sahuquet et al., 1990; Sahuquet and Ferrier, 1982; Union Oil Company of Canada Limited, 1975), SAGD and SC-SAGD (Grosmont) - each process exploits one or two predominant drive mechanisms (may vary with stages 
of application) to move heated oil to production wells. In TA-GOGD, the expanding gas cap and gravity drainage are the key mechanisms for moving oil to production wells. Early stages of CSS are usually dominated by formation re-compaction and the solutiongas drive, whereas later cycles are dominated by gravity drainage. The primary driving force in SAGD and SC-SAGD is gravity drainage of heated oil into a production well usually placed a few meters below an injection well. Steamflooding, however, exploits the external pressure-drive for this purpose. The applicability and efficiency of each method depends on reservoir configuration, properties and initial conditions. As an example, although heat transmission into the reservoir during CSS in oil sands is facilitated by steam fracturing in early cycles, the implications of fractures, vugs and caverns for a similar process in the uniquely complex Grosmont geology is less obvious. Nevertheless, high injectivity recorded during early Grosmont pilots is ascribed to the network of fractures. A critical analysis of Grosmont pilot data will reveal where a window of opportunity exists for exploiting certain recovery technologies which may have been absent during these early pilots.

Somewhat traditional pessimism associated with Enhanced Oil Recovery (EOR) from carbonates (typically fluid injection), the low market price of bitumen and the mixed results from earlier pilots have hampered commercial development of Grosmont. To date, no commercial projects have been operated in Grosmont and as a result, reserve estimates are yet to be made by the regulatory authority (Energy Resources Conservation Board, ERCB) in Alberta. Although a price differential still exists for heavy crude compared with lighter crude, a high 5-year average value of about US\$70 per barrel for the Canadian benchmark heavy crude (West Canadian Select) makes prospects for Grosmont commercialization attractive. In addition, an excellent opportunity lies in an in-depth analysis of previous Grosmont pilots conducted by Alberta Oil Sands Technology Research Authority (AOSTRA), Union Oil Company of Canada Limited (UNOCAL) and Canadian Superior, in the light of technological advancement in bitumen recovery. This paper presents a condensed analysis based on a comprehensive integration of early pilots (between 1975 and 1987) which serves to ascertain to what degree factors such as the reservoir, fluid properties and operational variables affected recovery performances in comparable bitumen carbonates. Such insight is then integrated into currently available technology to inform viable ideas for commercial development of the Grosmont bitumen carbonate. Bitumen production from a SAGD pilot which became operational in 2010 offers additional opportunities for future evaluation of bitumen carbonate development and in particular, Grosmont, based on field experiences.

\section{GEOLOGY AND DIAGENESIS}

The Grosmont is an Upper Devonian shallow marine to peritidal platform with coarsening-up carbonate sequences. Efforts to characterize carbonate-bitumen deposits in Alberta have been ongoing since the 1980s (Harrison and McIntyre, 1981; Theriault and Hutcheon, 1987; Theriault, 1988). A SW-NE stratigraphic section highlighting Grosmont Formation in relation to other key successions in northern Alberta is shown in Figure 1. The Grosmont carbonate strata dip gently $(\approx 0.3$ to 1 degree) westward and are underlain by the shaley limestones and shales of the Lower Ireton Formation (Walker, 1986; Luo and Machel, 1994). It is conformably overlain by the Upper Ireton Formation and the Nisku Formation, while the McMurray Formation overlays it along the sub-Cretaceous unconformity. The Grosmont Formation is divided into four units; A, B, C and D (formerly described as LG, UG1, UG2 and UG3, respectively), where $\mathrm{A}$ is the lowermost unit and $\mathrm{D}$ is the uppermost. Each of the four units is separated from the other by marl (i.e. a calcium carbonate which contains variable amounts of clays and aragonite) layers. The C$\mathrm{D}$ marl (i.e. marl separating the $\mathrm{C}$ and $\mathrm{D}$ units) occurs at $346 \mathrm{~m}$ (Edmunds et al., 2009). The most prolific hydrocarbon reservoirs (based on porosity and thickness) are the $\mathrm{C}$ and $\mathrm{D}$ units, which contain $80 \%$ of total Grosmont bitumen in-place. The geologic sequences represent a series of diagenetic events on sediment deposits, culminating in dolomitization, uplift, erosion and karstification to produce a highly heterogeneous reservoir containing

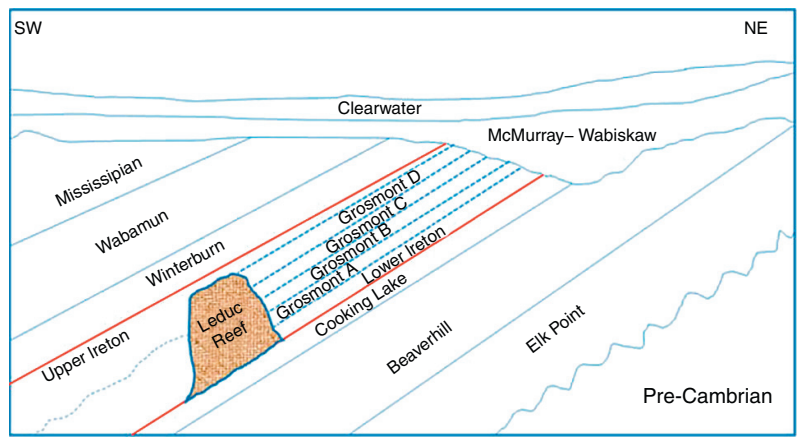

Figure 1

A SW-NE stratigraphic section highlighting Grosmont Formation. 
heavily degraded oil (bitumen). In summary, the Grosmont carbonate reservoirs are highly heterogeneous.

Dolomitization and karstification processes which occurred during the diagenesis of Grosmont formation resulted in a near complete dissolution of calcite within the $\mathrm{C}$ and $\mathrm{D}$ units, leaving nearly pure dolomite. Some of the dolomites have also been dissolved. Breccia (rubble) zones also formed following continued dissolution of rock by meteoric water and eventual collapse as the porosity of the zones reached $40 \%$ (Barrett et al., 2008). It is also interesting to note that features such as the breccia and mega-porosity zones are well correlated for distances of the order of $100 \mathrm{~km}$. The Grosmont also has very dense concentration of small (10-cm scale) subvertical fractures. These fractures are thought to have originated from stresses induced by local dissolution and/or differential collapse of lower zones. Vugs appear to be connected by these fractures and dissolution often led to further widening of the fractures. Several fractures are commonly observable in a single cross-section of a core. The average porosity of the $\mathrm{C}$ and $\mathrm{D}$ units is about $20 \%$, while a porosity range of 5 to $40 \%$ has been reported for individual units. Tomography studies suggest that more than half of the total porosity is greater than $0.5 \mathrm{~mm}$ (pore diameter or fracture width) and about $100 \mathrm{mD}$ matrix permeabilities are typical in Grosmont.

The diagenesis of the Grosmont Formation has been presented in the literature and involves a significant number of events in a paragenetic sequence (Luo and Machel, 1995; Buschkuehle et al., 2007; Machel and Hawlader, 1990). The paragenetic sequence that describes Grosmont's diagenetic processes can be presented in a chronological order of the first appearance of an event. However, several events occurred more than once and it is therefore significantly more insightful to classify the paragenetic sequence based on the burial history of the Grosmont area. We therefore adopt the approach presented in Buschkuehle et al. (2007) and describe the main diagenetic features at Grosmont, synchronous with the burial history of the area, within a group of three (3) time periods, as illustrated in Figure 2.

\subsection{Late Devonian to Early Mississippian}

Shallow water marine deposits were formed followed by calcite cementation and an early dolomitization episode. An early fracture event related to desiccation and dewatering also occurred. These were then followed by sediment compaction resulting in an increase in burial depth to about $700 \mathrm{~m}$. Dolomitization, sulfate dissolution and local precipitation of anhydrite also occurred simultaneously. Dissolution of evaporite minerals

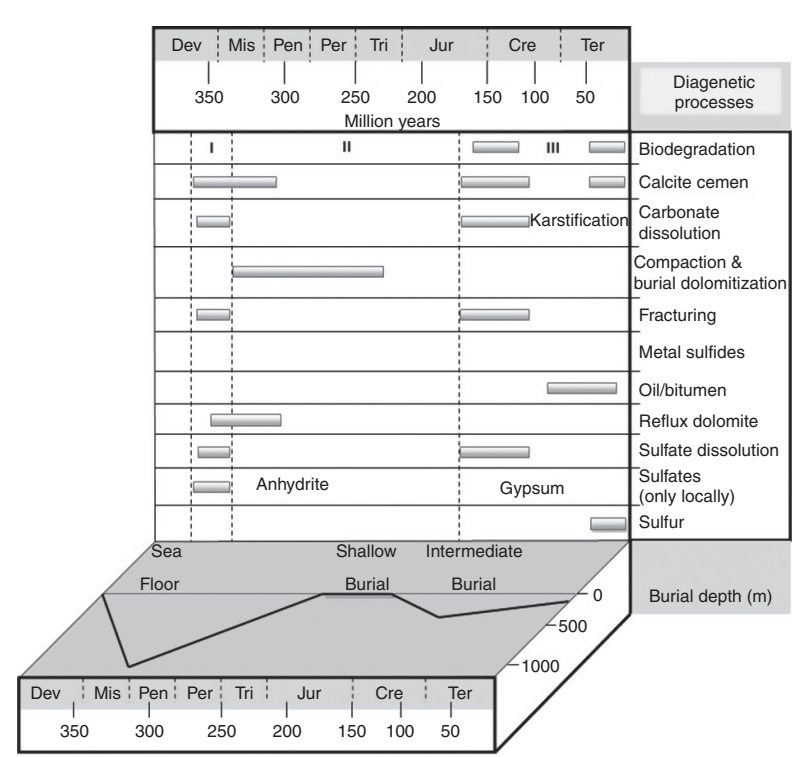

Figure 2

Diagenetic sequence in Grosmont platform categorized into three main stages: (I) early stage, late Devonian (Dev) to early Mississippian (Mis); (II) middle stage, early Mississippian (Mis) to late Jurassic (Jur); (III) late stage, late Jurassic to Tertiary (Ter). Other abbreviations include: Pen (Pennsylvanian), Per (Permian), Tri (Triassic), Cre (Cretaceous). Revised from Buschkuehle et al. (2007).

produced moldic and vuggy porosity (Luo and Machel, 1994; Buschkuehle et al., 2007).

\subsection{Early Mississippian to Late Jurassic}

This stage of diagenesis was characterized by continuing precipitation, compaction, dolomitization and dissolution of anhydrite. Uplift of the sediment to intermediate depths also occurred during this period (Buschkuehle et al., 2007).

\subsection{Late Jurassic to Tertiary}

Several crucial events occurred during this stage of diagenesis including uplifting, tilting, erosion, karstification, oil migration and biodegradation. Uplifting continued during this stage, resulting in sediments being uplifted to shallow burial depth. This eventually led to erosion and karstification. Karstification played a dominant role in the evolution of reservoir properties and this is indicated by the peak amount of secondary/tertiary dissolution porosity and oil saturation near the sub-Cretaceous unconformity (Luo et al., 1993). While karstification contributed significantly to producing high 
TABLE 1

Average reservoir properties of the Grosmont (ERCB, 2011)

\begin{tabular}{|c|c|c|c|c|}
\hline Grosmont zones & $\begin{array}{l}\text { Average pay thickness } \\
(\mathrm{m})\end{array}$ & $\begin{array}{c}\text { Water saturation } \\
(\%)\end{array}$ & $\begin{array}{l}\text { Porosity } \\
(\%)\end{array}$ & $\begin{array}{l}\text { Initial bitumen in-place } \\
\qquad\left(10^{6} \mathrm{~m}^{3}\right)\end{array}$ \\
\hline D (UG3) & 21.0 & 19 & 23 & 32860 \\
\hline $\mathrm{C}$ (UG2) & 13.6 & 22 & 17 & 18755 \\
\hline B (UG1) & 4.9 & 24 & 15 & 4450 \\
\hline $\mathrm{A}(\mathrm{LG})$ & 6.5 & 28 & 14 & 8472 \\
\hline
\end{tabular}

porosity, it compromises seal integrity, which is vital for selecting in situ recovery schemes. Oil migration then occurred, followed by degradation and enrichment with sulfur. Degradation of oil to bitumen was mainly by biodegradation (Brooks et al., 1988). Diagenesis influenced fundamental Grosmont reservoir properties, a summary of which is listed in Table 1.

\section{RESEARCH SCOPE AND METHODS}

\subsection{Research Scope}

In the late 1970s and early 1980s, thermal EOR pilots were conducted by AOSTRA, UNOCAL and Canadian Superior in the Grosmont Formation, mostly in Grosmont Zone C (formally named UG2), to evaluate the productivity of CSS, steam drive or steamflooding and In Situ Combustion (ISC). Vertical wells were used for all the pilots performed during this period and documented in various reports (Union Oil Company of Canada Limited, 1975, 1977, 1980, 1982-83; Chevron Canada Resources Limited, 1983; Ziegler and Bay, 1984; Ziegler, 1985). Due to poor results from the steamflood pilots, most of the pilots were tested on CSS. Results from these Grosmont pilots have generally been described as 'mixed'. Some of these CSS pilots gave very encouraging bitumen production rates and cumulative Steam-Oil Ratio (cSOR) - comparable with CSS in Clearwater sandstone reservoirs - while very poor bitumen production and cSOR were recorded in some other Grosmont CSS pilots. The first aim of this research is to understand the performances of early Grosmont pilots and the finer details of how reservoir, operational and available technology influenced performances, Figure 3. A second goal is to explore how current commercial technology can be adapted and recommend EOR technology and modifications with more potential to facilitate commercial development of the Grosmont carbonate reservoirs. Bearing in mind that these early pilots mostly utilized steam and the mature commercial

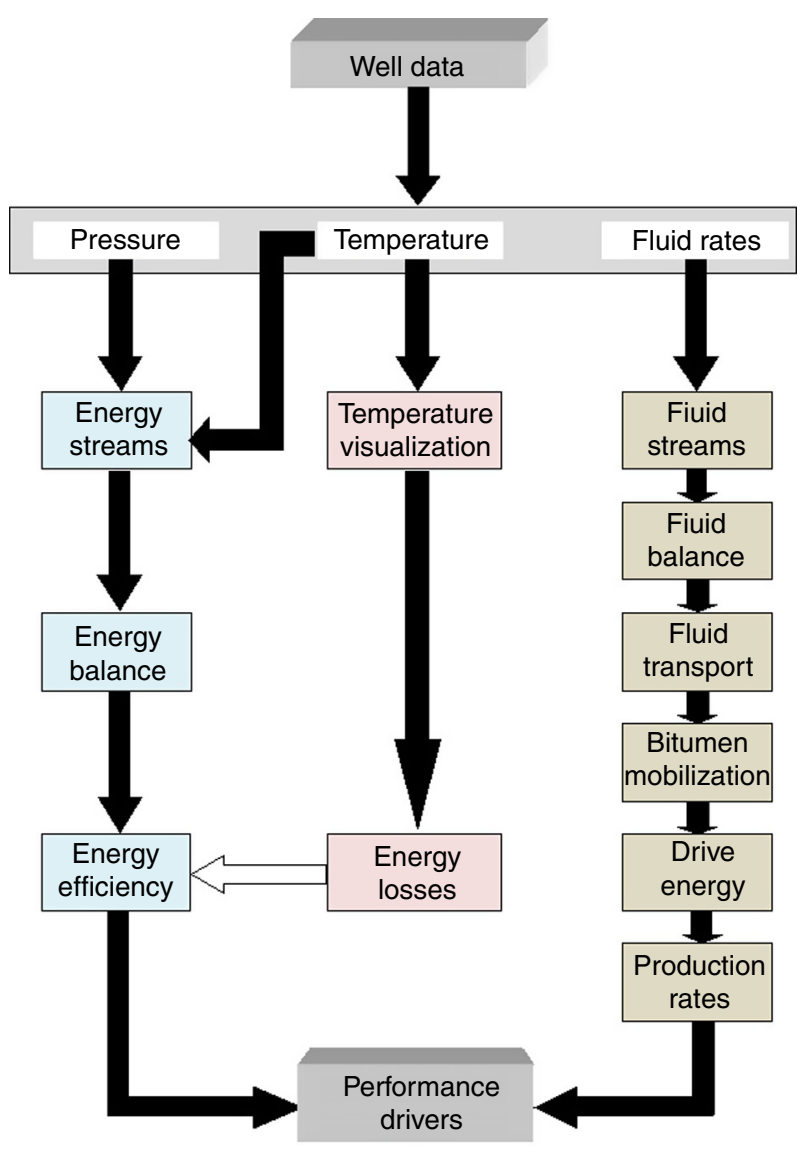

Figure 3

Flowchart describing process workflow applied for pilot history analysis.

development of steam technology for heavy oil/bitumen recovery, we focus our discussion on steam-based EOR.

To achieve the defined research goals, a three-part work flow was designed that describes the research scope and consists of:

- fluid analysis (including the impact of the aquifer),

- energy flow analysis,

- spatial temperature time-lapse analysis. 
The implications of each phase of the three-part work flow are systematically evaluated individually and in an integrative manner. Indices for pilot performance include the bitumen production rate, steam-oil ratio and degree of steam conformance.

\subsection{Methods}

About 203 digital datafiles were analyzed during this research. A consistency quality check was performed to reconcile information in different reports with raw data. Details of the scheme employed for data analysis and energy balance calculations are summarized below:

1. the steam injection volume $Q_{w}$ for each cycle, Cold Water Equivalent (CWE), was calculated from daily injection raw data $\left(q_{w}\right)$ cumulated over injection periods $(t)$ as described by:

$$
Q_{w}^{c y c l e}=\sum_{t_{\text {start }}}^{t_{\text {end }}} q_{w} \times t
$$

2. the initial reservoir temperature for each well was calculated from the arithmetic average of all thermocouple temperature readings for the well;

3. the injected energy for each cycle was calculated by summing daily energy injection for the duration of each cycle. Equation (2) describes the calculation of injected energy:

$$
\dot{Q}=\sum \dot{m}\left[c_{l} \Delta T+f\left(h_{v}-h_{l}\right)\right]
$$

where $\dot{m}$ is the mass rate of steam injection, $f$ is the injected steam quality, $c_{l}$ is the specific heat capacity of liquid, $\Delta T$ is the temperature difference, $h_{\mathrm{v}}$ is the specific vapor enthalpy and $h_{l}$ is the specific liquid enthalpy;

4. the net injected energy for each cycle was calculated as the difference between injected energy and sensible heat of water at the initial reservoir temperature specific heat capacity of liquid water was assumed to be $4.1805 \mathrm{~kJ} / \mathrm{kgK}$;

5. the sensible heat of produced bitumen in each well was calculated from the average production temperature, the mass of bitumen produced in the cycle (bitumen density approximated to $1037 \mathrm{~kg} / \mathrm{m}^{3}$ ) and the specific heat of bitumen (derived from correlation) at the production temperature (Gates, 2011). A similar approach was used to calculate the sensible heat of produced water, assuming water density of $1000 \mathrm{~kg} / \mathrm{m}^{3}$;

6. to obtain the net produced energy in water (for each cycle), the sensible heat of produced water was calculated by using the heat capacity of water at the initial reservoir temperature and subtracted from injected energy. This was also calculated for the bitumen phase;

7. the net energy balance was calculated as the difference between net injected energy (steam) and produced energy (water + bitumen). This represents the amount of energy retained in the reservoir and/ or lost to the surroundings. Visualization of 3D temperature profiles revealed the retention or loss of heat energy beyond the conformance zone;

8. the fraction of energy produced was calculated as the ratio of net produced energy to the net injected energy. Similarly, the fraction of energy lost was calculated as the ratio of net lost energy (injected energy - net produced energy) to the injected energy;

9. it is important to state that the energy balance calculations presented here did not incorporate the sensible heat of produced sediment. The implication is that calculated energy lost may be slightly higher than actual energy lost. The reference state chosen for the energy calculations was liquid at the initial reservoir temperature;

10. the steam-to-oil ratio was calculated as the ratio of CWE volume of injected steam to the volume of produced bitumen for each cycle (cyclic SOR, cySOR) and for all the cycles (cumulative SOR, cSOR).

The majority of key pilot tests were conducted at the Buffalo Creek and McLean sites. Regardless, a brief analysis of the Chipewyan River pilot is presented in the next section based on insights from available data. This is then followed by a more concentrated analysis of the Buffalo Creek and McLean pilots.

\section{CHIPEWYAN RIVER PILOT (SECTION 21, TOWNSHIP 89, RANGE 21, W4M)}

Pilot tests in Chipewyan River were conducted in two phases, jointly by UNOCAL, AOSTRA and Canadian Superior Resources (CSR). The first phase was in 1975 and comprised of air injection, followed by a single-cycle CSS in two wells, 14B-21-89-21 W4M (tested zone C of the Grosmont) and 11E-21 (tested zone $\mathrm{D}$ of the Grosmont), summarized in Table 2. Following 23 days of steam injection into Well 14B-21, reservoir pressure measured at the well increased from an initial value of $1255 \mathrm{kPa}$ to $6550 \mathrm{kPa}$. Also, more than $4000 \mathrm{kPa}$ increase in reservoir pressure was recorded after 16 days of steam injection into Well 11E-21. Despite the large pressure increase, no evidence of hydraulic fracturing was reported. The pilot exhibited good injectivity, with the water injection rate in each well averaging more than $18.7 \mathrm{~m}^{3} / \mathrm{d}(118 \mathrm{bbl} / \mathrm{d})$. During the production cycle, bitumen flow rates dropped to about $0.16 \mathrm{~m}^{3} /$ day $(\approx 1 \mathrm{bbl} / \mathrm{d})$ 
TABLE 2

Summary of Chipewyan River Pilot data. cySOR is the cyclic steam-to-oil ratio (steam expressed as CWE volume)

\begin{tabular}{|c|c|c|c|}
\hline \multirow[t]{2}{*}{ Well } & \multicolumn{2}{|c|}{ Phase 1 (1975) } & \multirow{2}{*}{$\begin{array}{c}\text { Phase } 2 \text { (1977) } \\
\text { 14C-21 (Zone D) }\end{array}$} \\
\hline & 14B-21 (Zone C) & 11E-21 (Zone D) & \\
\hline \multicolumn{4}{|c|}{ Variables } \\
\hline Formation pressure $(\mathrm{kPa})$ & 1255 & 1103 & 1103 \\
\hline \multicolumn{4}{|c|}{ Air injection tests } \\
\hline Injection rate $(\mathrm{cfm})$ & 350 & 350 & - \\
\hline Pressure $(\mathrm{kPa})$ & 2344 & 1586 & - \\
\hline \multicolumn{4}{|c|}{ Steam injection tests } \\
\hline Steam injection (days) & $\approx 23$ & $\approx 16$ & $\approx 61$ \\
\hline Pressure (kPag) & 6550 & 5171 & $7000-11032$ \\
\hline Volume $\left(\mathrm{m}^{3}\right)$ & 1970 & 1893 & 6551 \\
\hline Steam quality (\%) & - & - & 55 \\
\hline Soak period (days) & $\approx 6$ & $\approx 5$ & $\approx 3$ \\
\hline Production period (days) & $\approx 49$ & $\approx 33$ & $\approx 13$ \\
\hline Oil $\left(\mathrm{m}^{3}\right)$ & $10.3(20 \rightarrow 3$ BPD in 4 days $)$ & $2.7(5 \rightarrow 1$ BPD in 4 days $)$ & $27(12 \rightarrow 3$ BPD in 3 days $)$ \\
\hline Water $\left(\mathrm{m}^{3}\right)$ & 3037 & 2292 & 245 \\
\hline $\operatorname{cySOR}\left(\mathrm{m}^{3} / \mathrm{m}^{3}\right)$ & 191 & 701 & 243 \\
\hline
\end{tabular}

in less than 5 days and cumulative water production far exceeded the injected steam volume in both wells. The cSOR in Wells 14B-21 and 11E-21 were 191 and $701 \mathrm{~m}^{3} / \mathrm{m}^{3}$, respectively. Three scenarios have been identified as likely drivers of pilot performance:

- a combination of poor injection steam quality and heat loss to formation water contrived to produce very poor thermal viscosity reduction of bitumen;

- high permeability water zones were encountered which, in addition to being heat sinks, also delivered large volumes of water during the production cycle;

- in the absence of hydraulic fracturing during steam injection, the large externally induced pressure gradient drove injected fluids deep into the formation which in turn displaced oil from the near-wellbore regions of the reservoir.

The excessive production of water, while being undesirable, gave an important insight into pilot performance. There was certainly a driving energy to move reservoir fluid into the wellbore. Therefore, regardless of the exact individual or combination of scenarios that was in place, integration of available data strongly implicates poor bitumen mobilization as the key CSS pilot performance inhibitor.
A second phase single-cycle CSS test was conducted in 1977 in Well 14C-21, to evaluate the response of the Upper Ireton and Grosmont $\mathrm{C}$ reservoirs to steam injection, the effects of clay and to evaluate well completion techniques. Poor injectivity was evident during steam injection as indicated by very high injection pressure up to $11000 \mathrm{kPa}$. This was attributed to three cement squeezes performed during well completion. Poor quality of injected steam - averaging between 50 and $60 \%$ - was also reported. Recovery performance was poor, with the bitumen production rate declining to $0.47 \mathrm{~m}^{3} / \mathrm{d}(3 \mathrm{bbl} / \mathrm{d})$ within three days and cSOR averaging $243 \mathrm{~m}^{3} / \mathrm{m}^{3}$. It is noteworthy that despite the high cSOR, unlike the first pilot phase, most of the injected water was not produced. Loss of injected steam via a network of fractures, vugs and sinkholes is a very likely reason for this. Ultimately, a balance must be met to ensure injection pressures are high enough to overcome injectivity issues and distribute heat in the formation, but not excessive to induce steam losses and consequent poor bitumen mobilization. Optimized injection pressure promotes sufficient production to develop a sustainable vapor chamber required for the gravity drainage phase of CSS. In addition, effective thermal 
heating associated with steam zone conformance should stimulate other important thermal recovery processes such as thermal oil expansion, wettability reversal and $\mathrm{CO}_{2}$ production, which combine to improve bitumen release from the matrix into the wellbore, either directly or through interconnected fractures.

\section{BUFFALO CREEK PILOT (SECTION 5, TOWNSHIP 88, RANGE 19, W4M)}

The Buffalo Creek pilot was conducted by UNOCAL between 1980 and 1986 to test CSS in Well 10A completed on Zone $\mathrm{C}$ at a depth of $286 \mathrm{~m}$. A total of 12 steam cycles were conducted and spatial evolution of heated zones in the reservoir was monitored by four surrounding observation wells. Figure 4 shows the well configuration of Buffalo Creek pilot and indicates approximate distances between the injector/producer well from the observation wells. Compared with the Chipewyan River pilot, a significantly improved average injection steam quality of $80 \%$ was reported for Buffalo Creek.

\subsection{Fluid Stream Analysis}

Average injected steam slug volume per cycle for Well $10 \mathrm{~A}$ was about $7900 \mathrm{~m}^{3} \mathrm{CWE}$. A graph of time duration of injection, soak, production periods and bottomhole pressure, displayed in Figure 5, reveals that the ratio of production to injection times generally increased with an increase in the number of cycles. Impressive oil

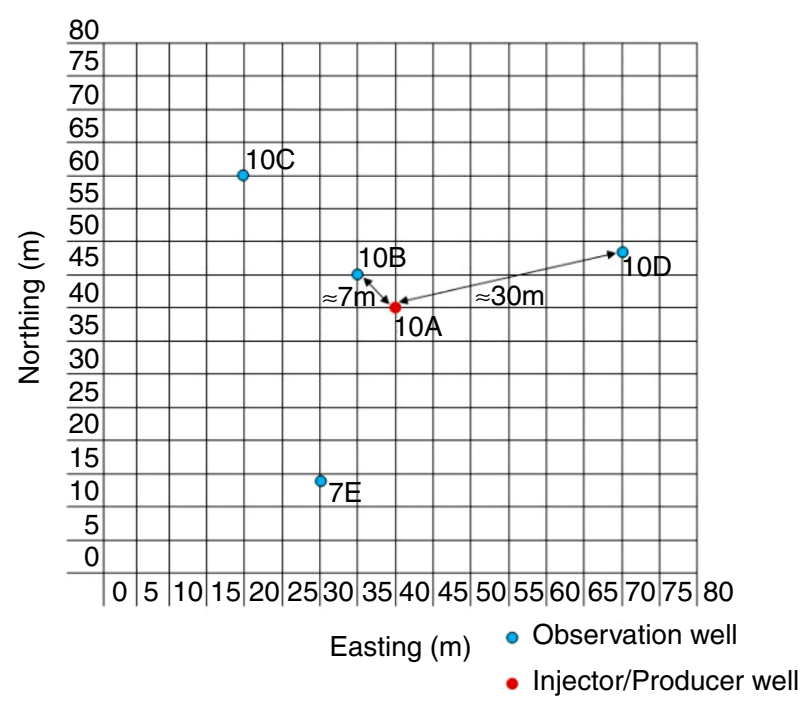

Figure 4

Buffalo Creek pilot well configuration. production rates as high as $70 \mathrm{~m}^{3} / \mathrm{d}$ were achieved. The volume of injected steam was doubled in Cycles 9 and 10 , resulting in relatively long injection times and equally long production periods. An important deduction from the bottomhole pressure plot is the good steam injectivity, which increased with the number of cycles. In Figure 5 , the bottomhole pressure history corroborates the trend in duration of phases for steam cycles and points towards good steam conformance. Injection pressure dropped from a peak value of over $4 \mathrm{MPa}$ in the first cycle to about $1.8 \mathrm{MPa}$ in Cycle 10. This is indicative of good steam conformance, which precludes the displacement of oil deep into the reservoir and away from the wellbore. In addition, good CSS steam conformance promotes gravity drainage of bitumen and offers additional energy for driving heated oil towards the wellbore, thereby improving late cycle recovery performance.

Figure 6 shows the cyclic volumes of injected steam (CWE) and produced liquid (bitumen + water). Effectively, cumulative injected volume surpassed produced volume throughout the CSS test periods, and this is indicative of fluid loss in the reservoir. Nevertheless, the cSOR declined from about $14 \mathrm{~m}^{3} / \mathrm{m}^{3}$ in the first cycle to a respectable value of about $5.8 \mathrm{~m}^{3} / \mathrm{m}^{3}$. Also noteworthy is the fact that except for Cycle 1 and Cycle 6, cyclic SOR for all cycles was less than $7 \mathrm{~m}^{3} / \mathrm{m}^{3}$, as shown in Figure 7. While a large cyclic SOR may be expected for the first cycle due to a poorly developed steam zone, increased cyclic SOR in Cycle 6 is attributed to the injection of a large volume $\left(3000 \mathrm{~m}^{3}\right)$ of hot water prior to the start of steam injection in this cycle. This was done to evaluate the possibility of improving bitumen production via a hot water pre-flood. The results, however, showed that hot water pre-flood neither improved oil production nor overall thermal efficiency. The poor performance of hot water pre-flood is intuitive considering that unlike steam, hot water only contains sensible heat which implies less thermal energy per unit mass of injected fluid. As a result, there was insufficient thermal mobilization and production of bitumen which eventually led to poorer growth of the steam conformance zone and the associated decline of gravity drainage.

Figure 8 shows net water injection or production for each cycle and cumulative for all cycles. Clearly, there was a net water injection for each cycle and overall. The net cumulative water injection at the end of Cycle 10 was $33000 \mathrm{~m}^{3}$, which translates to $60 \%$ recovery of injected water. Compared with the Chipewyan pilot, it is evident that heat loss to formation water or aquifer zones was minimal during the Buffalo Creek CSS pilot tests. At this point, we postulate that the CSS wells in the Buffalo Creek pilot traversed a favorable network of fractures such that steam injection was facilitated; 


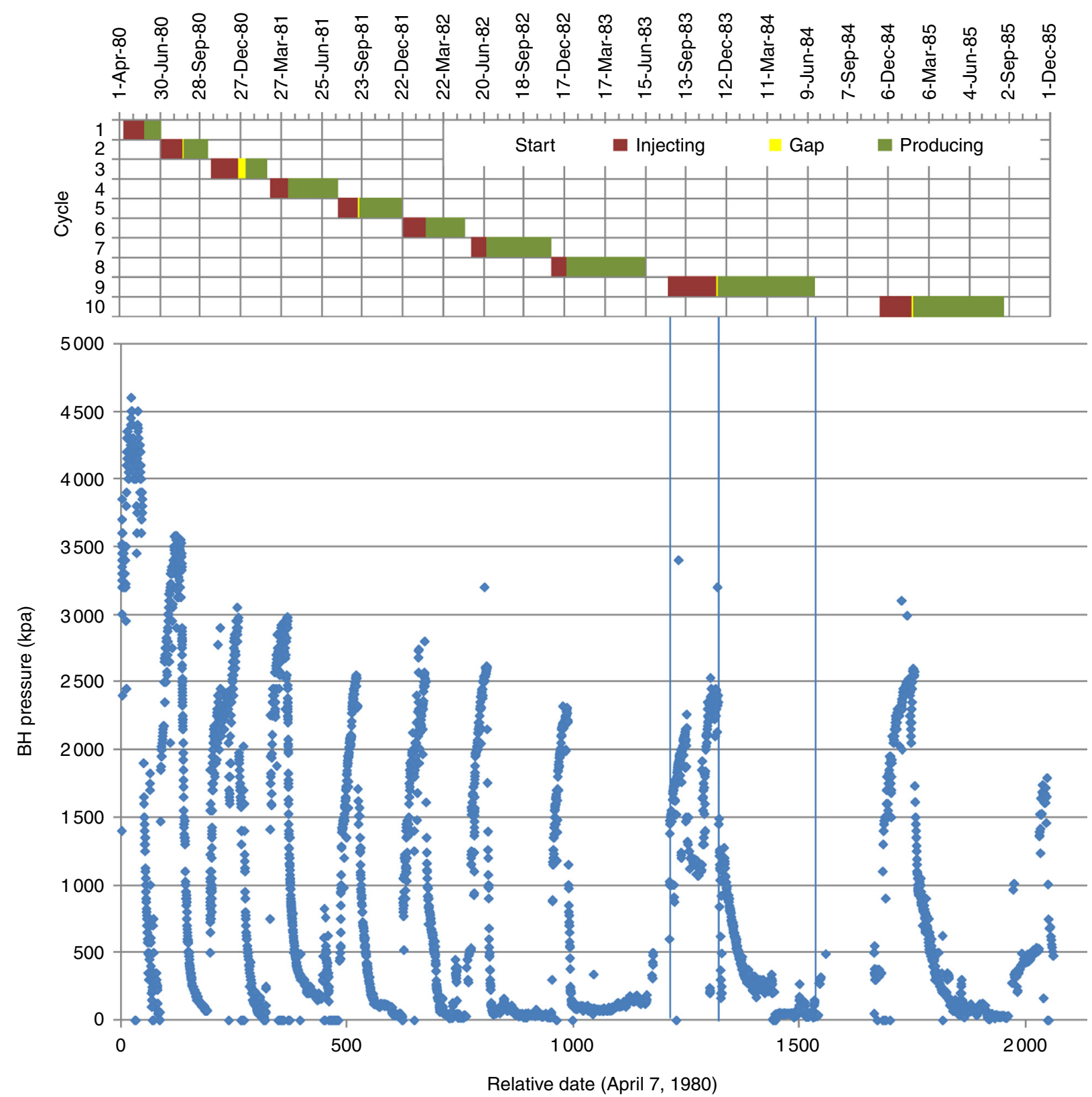

Figure 5

Graphical representation of time duration for steam injection, soak (shown as GAP) and production phases; the bottom plot shows bottomhole pressure for each cycle of Buffalo Creek CSS pilots.

similar to induced fractures in sandstone CSS projects. This ensured that injection pressure was low enough to prevent displacement of heated bitumen too far away from the wellbore, while also providing an effective steam conduit for convective and conductive heating of a large reservoir volume. The subsequent energy balance analysis will also test the accuracy of this postulation.

\subsection{Energy Balance Analysis}

We analyzed the energy balance during each CSS cycle to ascertain how much of the injected energy (sensible and latent heat) was produced or retained in the reservoir using an initial reservoir temperature of $12^{\circ} \mathrm{C}$. This information was combined with the spatial temperature 


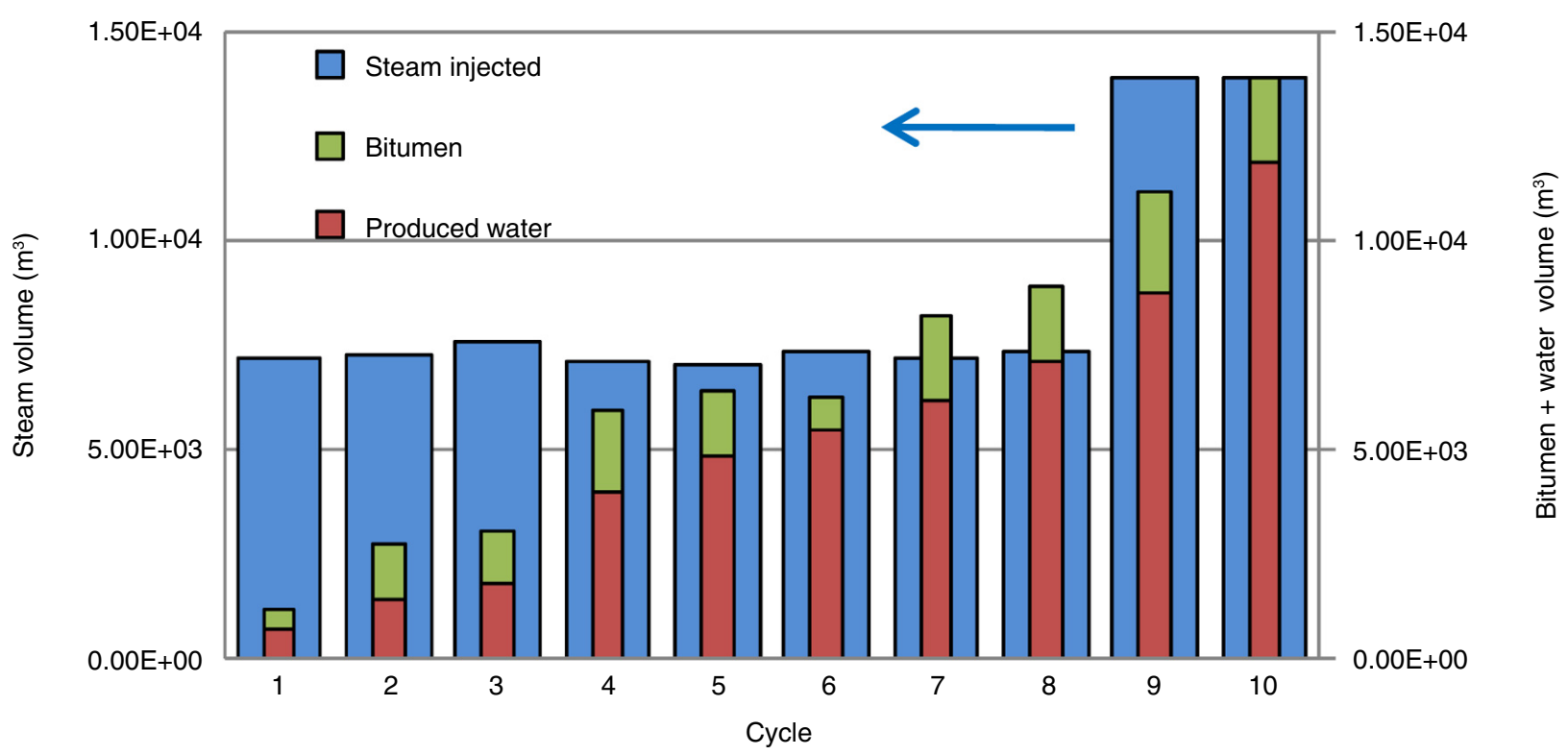

Figure 6

Cyclic volumes of injected steam and produced fluid during Buffalo Creek CSS pilots.

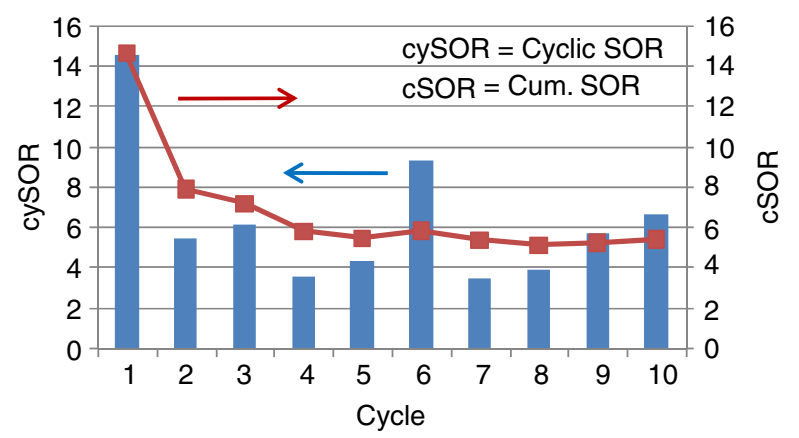

Figure 7

Cyclic and cumulative steam-to-oil ratio for Buffalo Creek CSS pilots.

profile to diagnose whether this energy was within the steam conformance zone or lost to sinkholes and vugs. Figure 9 shows the result of energy calculations for injected energy (sensible + latent heat) and produced energy (sensible heat). It is evident that as a result of consistent injection volumes of fairly high-quality steam $(\approx 80 \%)$, the corresponding amounts of injected energy for the first 8 cycles are comparable. Although less than $2 \%$ of injected energy was produced in Cycle 1 , it increased to more than $14 \%$ by Cycle 8 . This was a combined effect of the reservoir getting warmer and an increased production volume. A doubling of injected steam volume in Cycles 9 and 10 had a reverse effect

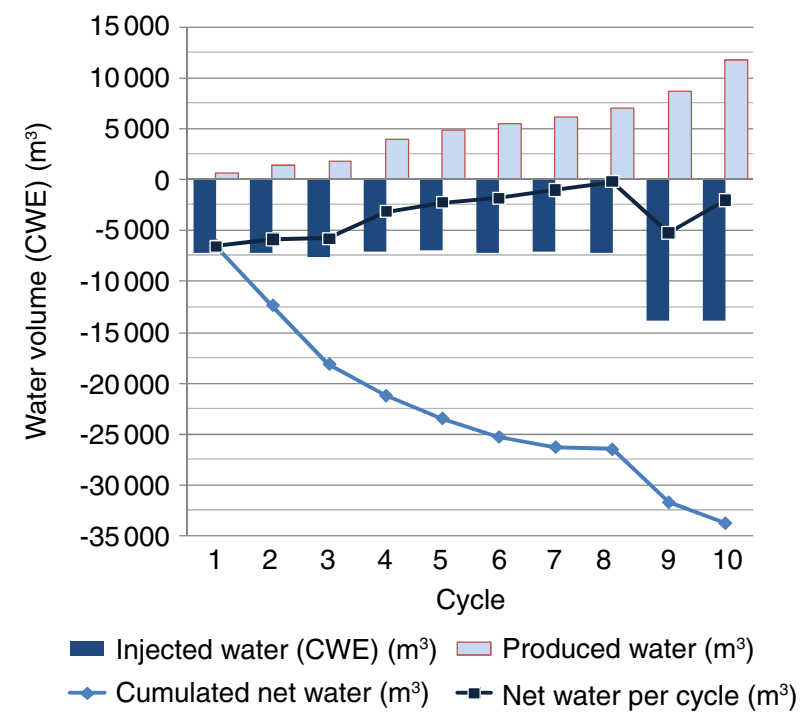

Figure 8

Water balance for Buffalo Creek CSS pilot showing a net water injection of $33000 \mathrm{~m}^{3}$ corresponding to $60 \%$ recovery of injected water.

on produced energy. This may be due to the displacement of injected fluid too far from the wellbore by an excessively large injected slug. It therefore appears that the more appropriate size of injection slug for the Buffalo Creek CSS pilot was in the range of $7000 \mathrm{~m}^{3}$. Further 


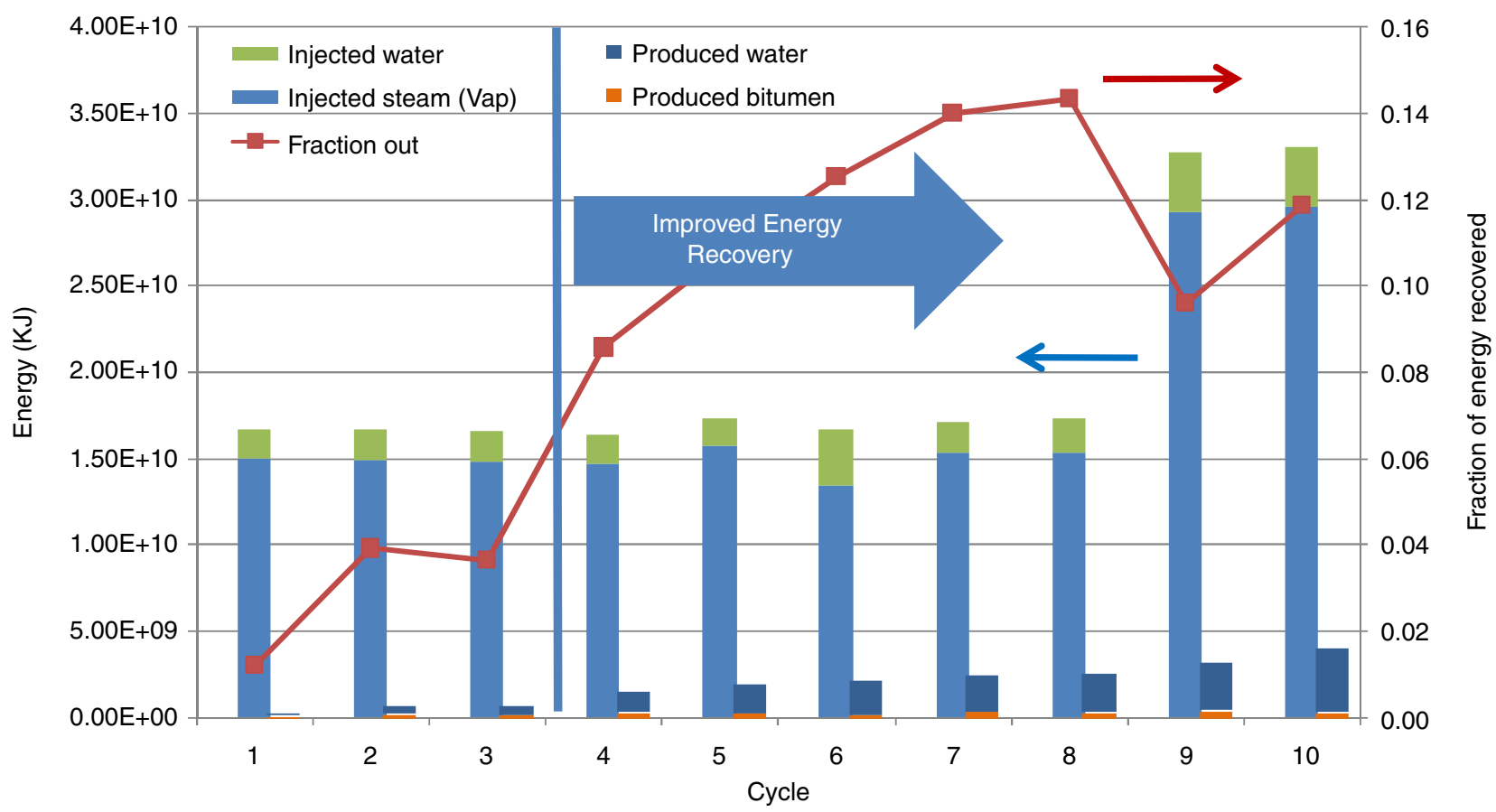

Figure 9

A plot of energy distribution within injected and produced fluids during Buffalo Creek CSS pilots.

analysis of the overall energy balance for all cycles showed that only about $9 \%$ of injected energy was produced and that produced bitumen contained about $1 \%$ while the rest was in produced water. Considering that $90 \%$ of injected energy was retained in the reservoir, it is important to understand how this energy was distributed to conceptualize and engineer improved CSS design. Figure 10 shows that a large portion of the retained energy was outside the steam conformance zone. The magnitude of energy lost outside the steam conformance zone in Cycles 9 and 10 corroborates our earlier assertion that the injected slug size in those cycles $\left(\approx 14000 \mathrm{~m}^{3}\right)$ was excessive for this pilot and detrimental to heat retention in the steam conformance zone. The correlation between a number of performance indices and bottomhole injection pressure was evaluated and is presented in Figure 11. It emerged that a strong correlation $\left(r^{2}=0.78\right)$ exists between the fraction of energy produced and steam injection pressure. A small fraction of injected energy was recovered at high injection pressures (early cycles $\approx 4000 \mathrm{kPa}$ ) while significantly larger fractional energy recovery was calculated at lower (late $\approx 2000 \mathrm{kPa}$ ) injection pressures. This is consistent with observations from Figure 9. Cyclic SOR also shows a reasonable correlation with injection pressure and

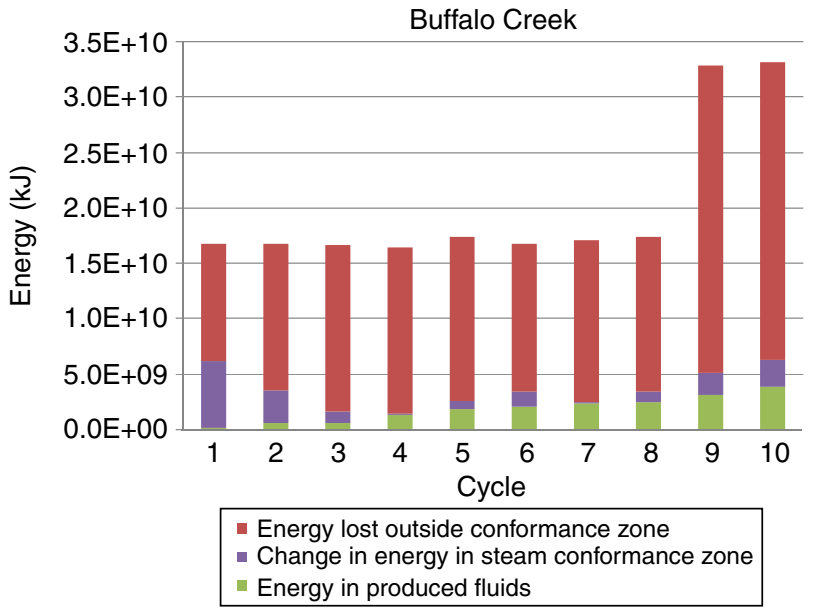

Figure 10

Overall energy balance for Buffalo Creek Pilot comparing energy retained in the conformance zone with that lost outside the conformance zone in each cycle. Total height of bars represents injected energy.

indicates an increase in cyclic SOR with increasing injection pressure. In contrast, the bitumen production rate and volumes are poorly correlated with injection 

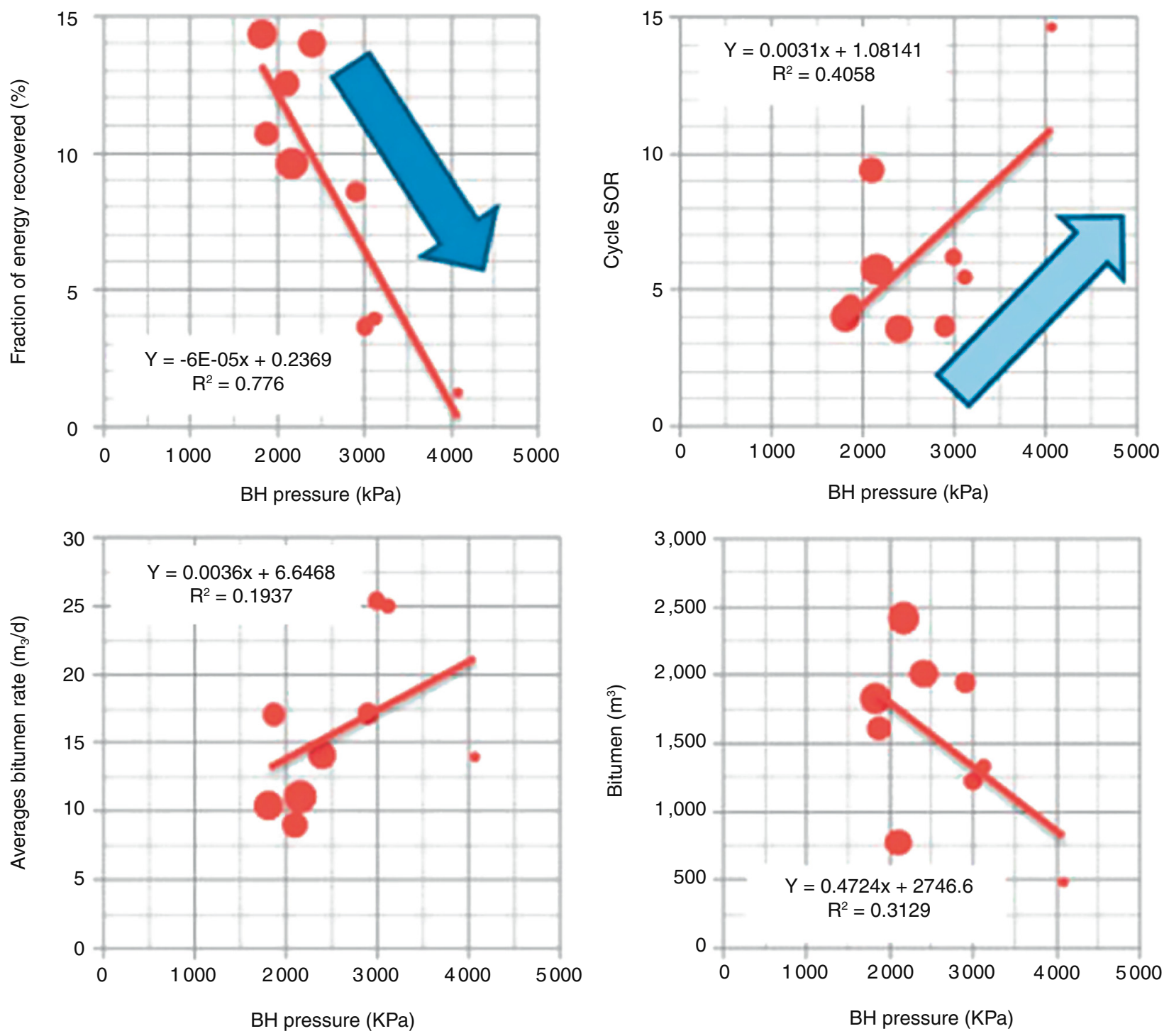

NOTE: Area of the circle corresponds to the cycle number

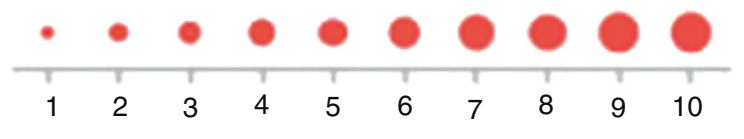

Cycle number

Figure 11

Effect of bottomhole injection pressure on selected performance indices during Buffalo Creek CSS pilots.

pressure when all the cycles are considered. However, the correlation factor for the bitumen rate versus injection pressure improves to around 0.63 when Cycle 1 is ignored. Considering that CSS is at a very early stage during Cycle 1, effective correlation may be more representative when Cycle 1 is ignored. Regardless, the produced bitumen volume remains poorly correlated to injection even without Cycle 1 data.

\subsection{Temperature Visualization}

Although temperature data for Well 10A were sparse, an extensive profile of temperature data was available for the observation wells. A rigorous quality check was conducted and an algorithm developed to transform this data into very informative $3 \mathrm{D}$ depth, time and space data, presented in Figure 12. At day 360, the CSS pilot 

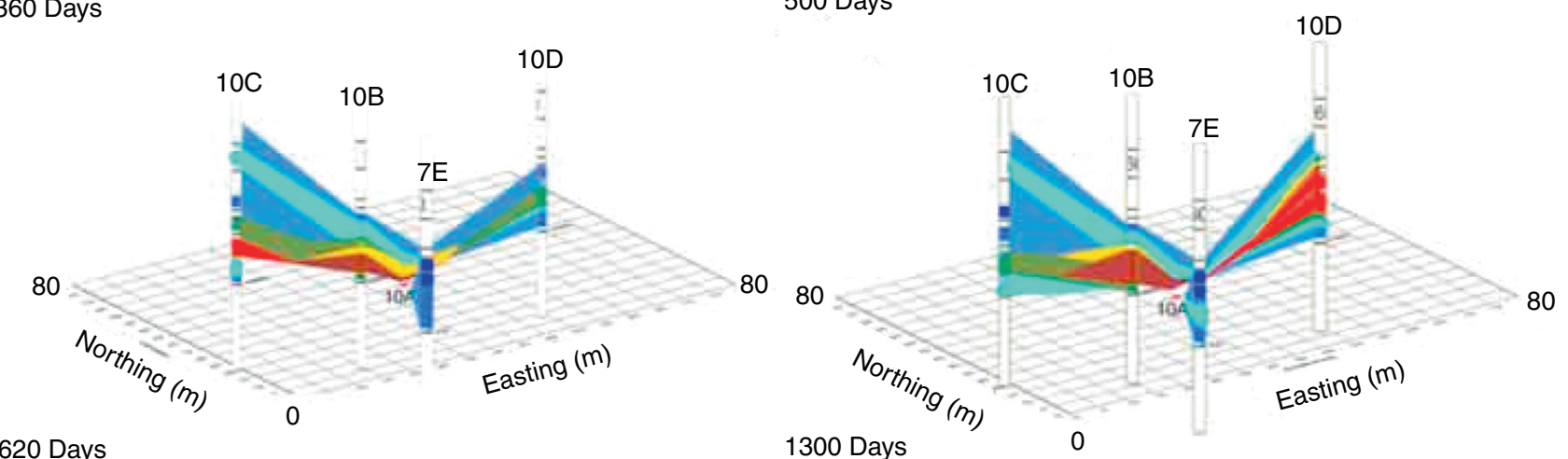

620 Days

$10 \mathrm{D}$

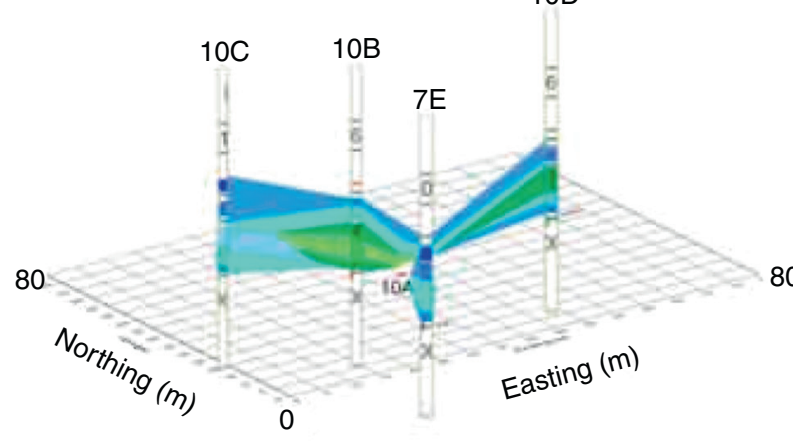

1300 Days

80
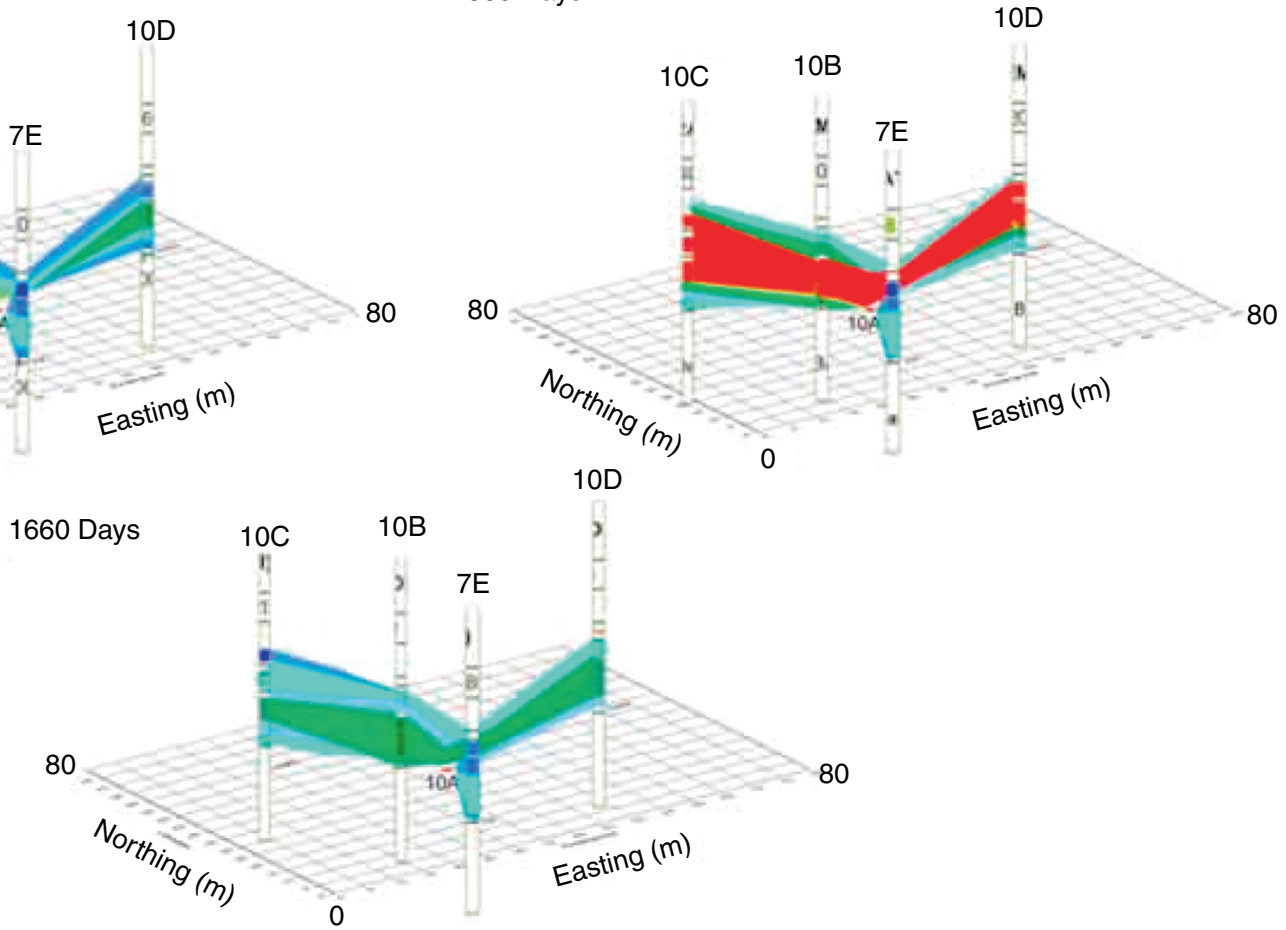

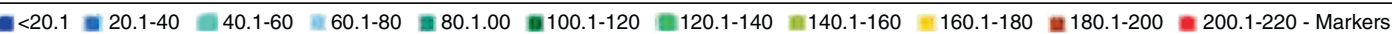

Figure 12

Graphical display of interwell spatial temperature at different time intervals representing injection or production during Buffalo Creek CSS pilot.

was on a production cycle and the very high temperatures $\left(>180^{\circ} \mathrm{C}\right)$ observed at Wells $10 \mathrm{~B}$ and $10 \mathrm{C}$ clearly indicate hydraulic communication in the NW direction. While this may facilitate heat distribution, it also highlights the likelihood of energy loss when excessively large injection slugs were implemented. Day 500 represents a Cycle 5 injection period while Day 620 is near the end of the Cycle 5 production interval. Day 500 shows that besides the NW direction, there is also hydraulic communication in the NE direction where temperatures exceeded $180^{\circ} \mathrm{C}$ at Well $10 \mathrm{D}$. In contrast, just over $40^{\circ} \mathrm{C}$ was recorded in Well 7E at Day 500 and this is attributed to conductive heating. The reservoir temperature in high temperature areas, however, dropped to less than $100^{\circ} \mathrm{C}$ close to the end of Cycle 5 production shown at Day 620 . Similar trends in heat distribution were also evident at Days 1300 and 1 660, which represent the Cycle 9 injection and end of production periods, respectively. Again, temperatures at Well 7E remained below $60^{\circ} \mathrm{C}$ during Cycle 9 steam injection. The drastic drop in temperature from above 200 down to $100^{\circ} \mathrm{C}$ during the production period of Cycle 9 (at Day 1 660) highlights inefficiency 
in the CSS process. This implies that during subsequent steam injection, a large heat loss occurred within the conformance zone and compromised heat that should have been delivered to bitumen at the conformance zone perimeter. Poor temperature communication at Well 7E demonstrates that owing to Grosmont reservoir heterogeneity, fluid displacement was directional rather than radial. Directional hydraulic communication can be associated with either a network of fractures, vugs and karsts or high permeability layering. In view of Grosmont stratigraphic information (Fig. 1), layering may play a role in promoting NE directional flow. However, in the absence of additional information, directional flow in the NW direction can only be attributed to a network of fractures, vugs and karsts.

\section{MCLEAN PILOT (SECTION 28, TOWNSHIP 87, RANGE 19, W4M)}

The generally successful Buffalo Creek CSS pilot was followed by the McLean Pilot about $3 \mathrm{~km}$ south of Buffalo Creek. The McLean pilot was conducted by UNOCAL with an initial inverted $10117-\mathrm{m}^{2}$ (2.5 acres) spaced five-spot pattern designed to test a steam drive process, as shown in Figure 13. Grosmont Zone C was the target reservoir at a depth of about $273 \mathrm{~m}$. Steam injection $(\approx 80 \%$ quality) commenced in 1982 and

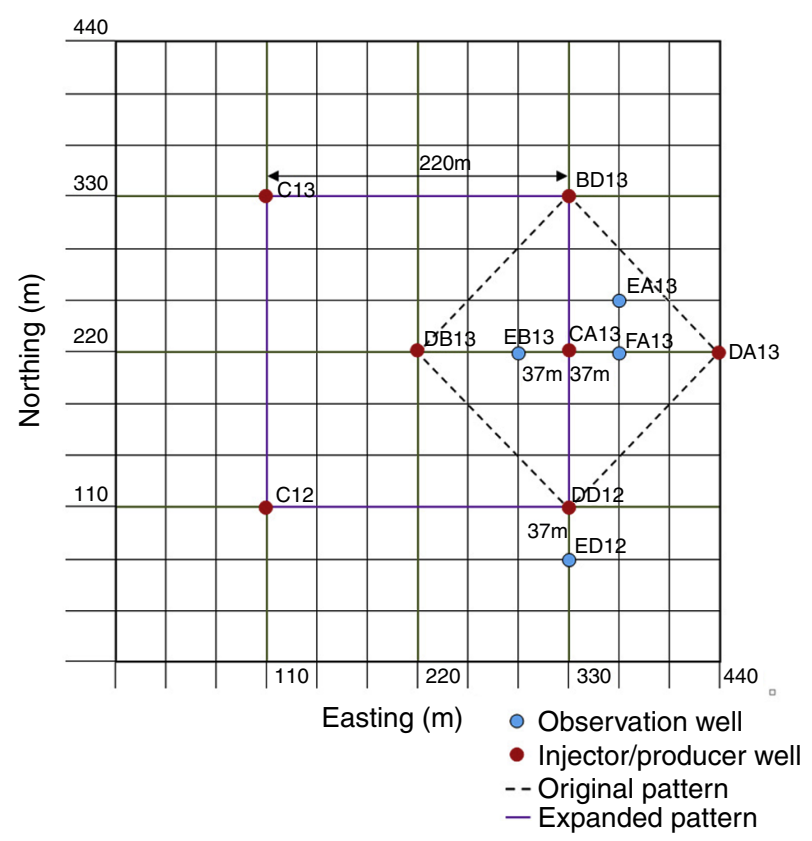

Figure 13

McLean pilot original (1982) and expanded (1984) patterns. terminated in 1987. In addition, three observation wells were drilled within the pattern, with an additional observation well south of the pattern. The initial steamflood test was designed to inject steam through Well CA13 and produce through the four corner wells. Unfortunately, just after about two days of steam injection in Well CA13, steam loss to the upper reservoir (Zone D) was observed through very high temperatures recorded at the observation well EA-13. This suggests that the shale layer separating Zones C and D (termed CD-Marl) was compromised. Further field investigation revealed a karst zone in place of the CD-Marl at a location near Well CA13 and this was deemed responsible for upward steam channeling to Zone D. To avoid process inefficiency associated with steam loss to the upper reservoir, Well CA13 was shut in and the corner wells (i.e. BD13, DB13, DA13 and DD12) were converted to CSS wells. Prior to a fourth CSS cycle, the McLean pilot was expanded in 1984 with the addition of two wells (C12 and C13) to create a larger 5-spot pattern. The measured bottomhole temperature of the new wells suggested that they were not affected by previous CSS cycles. However, three wells (BD13, DB13 and DD12) were part of both the old and expanded pattern, making it more difficult to interpret test results. cSOR varied from just above $100 \mathrm{~m}^{3} / \mathrm{m}^{3}$ to less than $5 \mathrm{~m}^{3} / \mathrm{m}^{3}$. There were several issues related to casing damage and production reported during this pilot. It is also noteworthy that the McLean pilot produced a significant volume of sediments. Nevertheless, some of the wells performed very well and achieved a peak bitumen production rate of $100 \mathrm{~m}^{3} / \mathrm{d}(628 \mathrm{bbl} / \mathrm{d})$.

\subsection{Fluid Stream Analysis}

It can be seen from Figure 14 that prior to pattern expansion, injection volumes per cycle (i.e. steam slug size) in all wells within the original pattern peaked at $7000 \mathrm{~m}^{3}$. However, while wells DB13 and DA13 achieved this peak steam slug size in Cycle 1, significantly lower volume was injected in wells BD13 and DD12 during this cycle. Considering that peak injection volumes were achieved by Cycle 3 in wells BD13 and DD12, the ramping up of injected steam in both wells was most likely due to operational issues related to reported casing problems rather than a reservoir effect. Throughout the operation of the original well pattern, the water produced from wells DD12 and DB13 was only a fraction of injected steam (CWE). In contrast, wells BD13 and DA13 produced more water than injected volume during Cycles 3 and 1, respectively. During Cycle 2 of the expanded pattern, a large net steam injection was recorded in Well DB13 and corresponded to a large net water production in Well BD13. This suggests a hydraulic communication between 

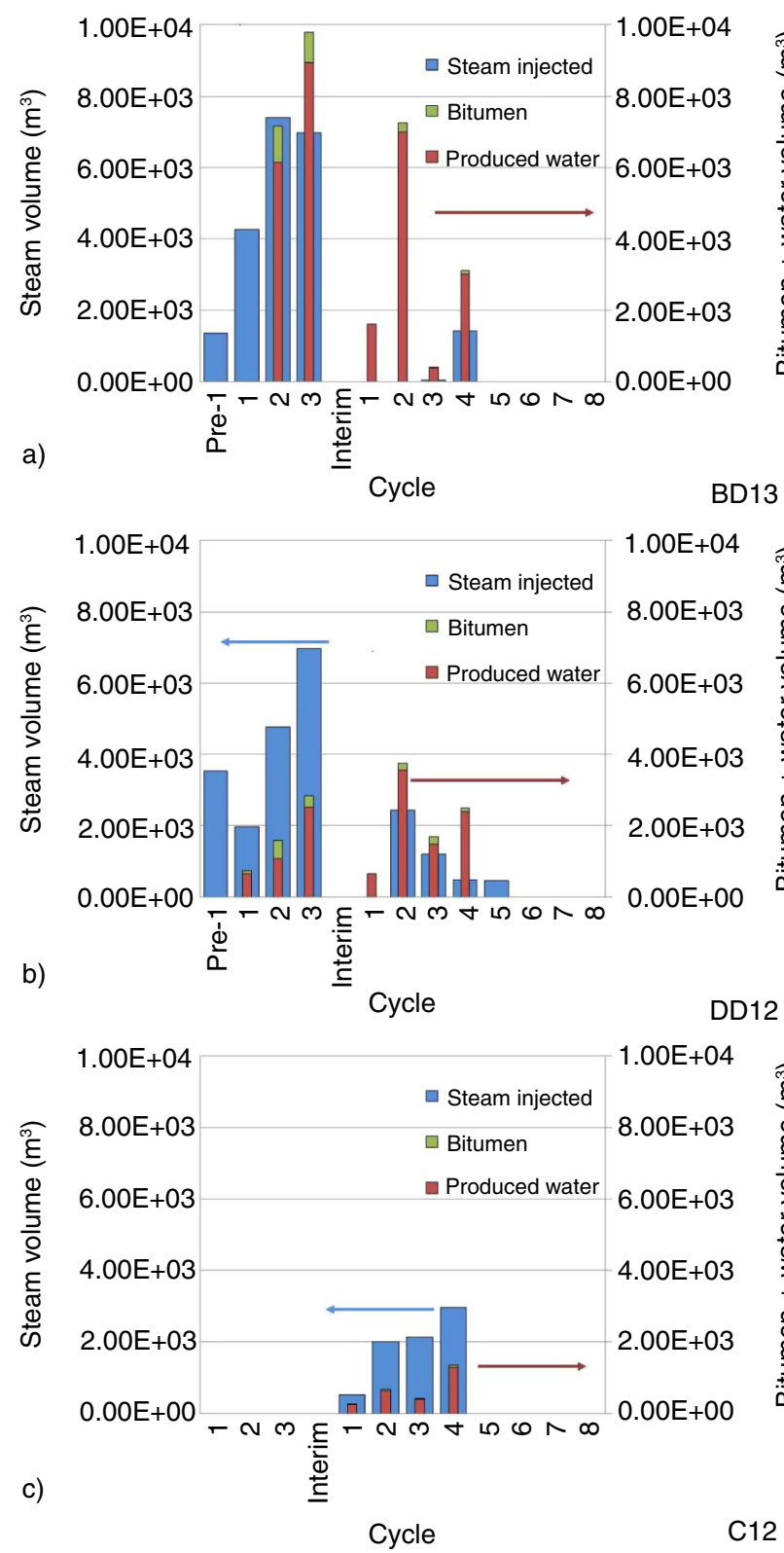

Figure 14

Cyclic injection and production volumes for different McLean pilot CSS wells. Interim indicates McLean pattern expansion and Well C13 was operated as a single CSS pilot from Cycle 5.
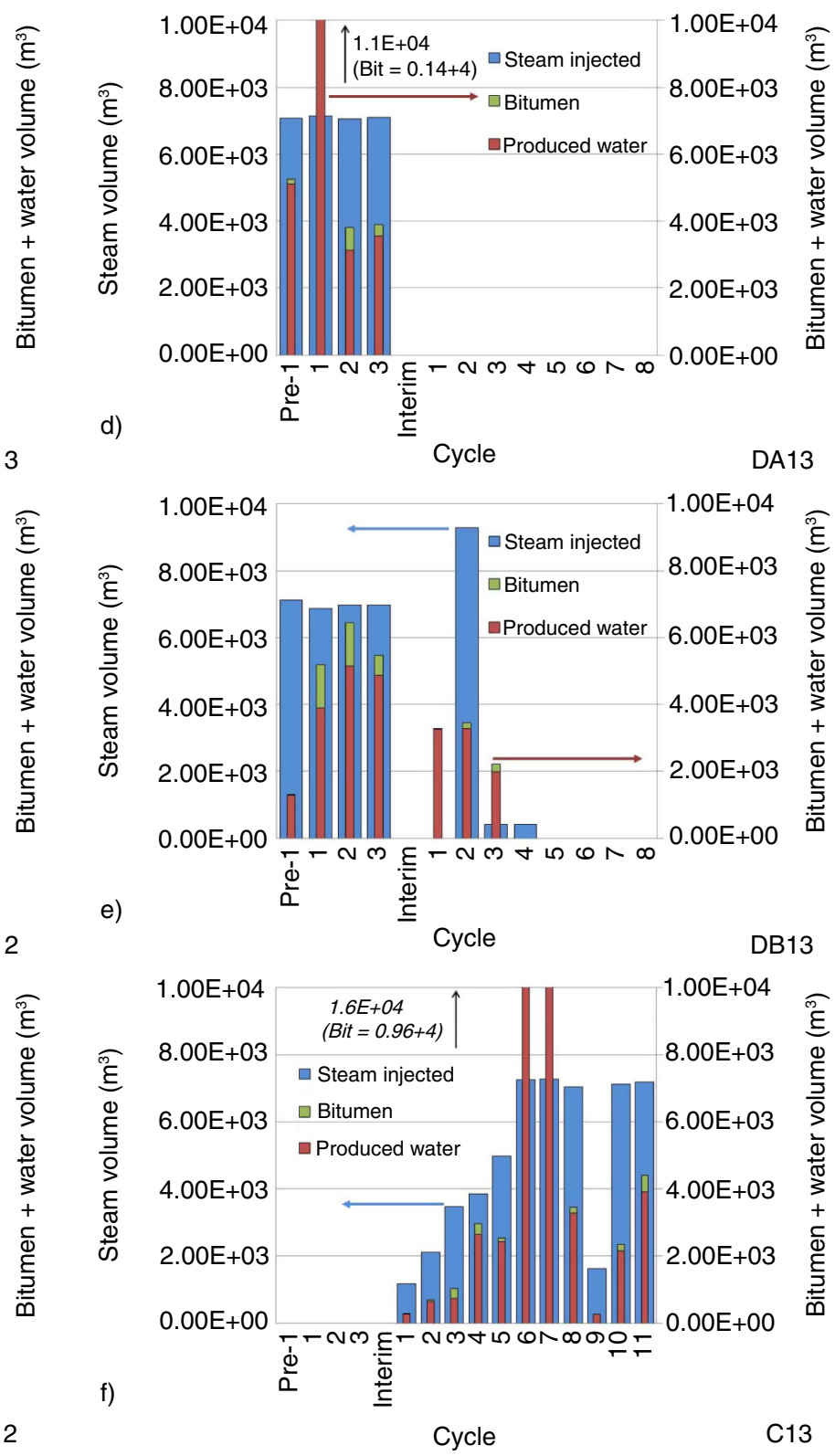

the wells and is consistent with the NE directional communication noted in the Buffalo Creek pilot. Well C12 produced an insignificant volume of bitumen, whereas Well $\mathrm{C} 13$ showed considerable cyclic variation between the volume of injected water and produced bitumen.

A foam (Chevron Chaser SD1000) pilot test was conducted on Well C13 during Cycle 9 to evaluate its ability to improve steam conformance. The foam test was deemed successful based on increased bitumen production volume in Cycles 10 and 11 , as displayed in Figure 14. This suggests that CSS bitumen recovery from Grosmont can be improved by mitigating excessive steam channeling. Figure 15 shows that excluding wells $\mathrm{BD} 13$ and $\mathrm{C} 12$, the cumulative 

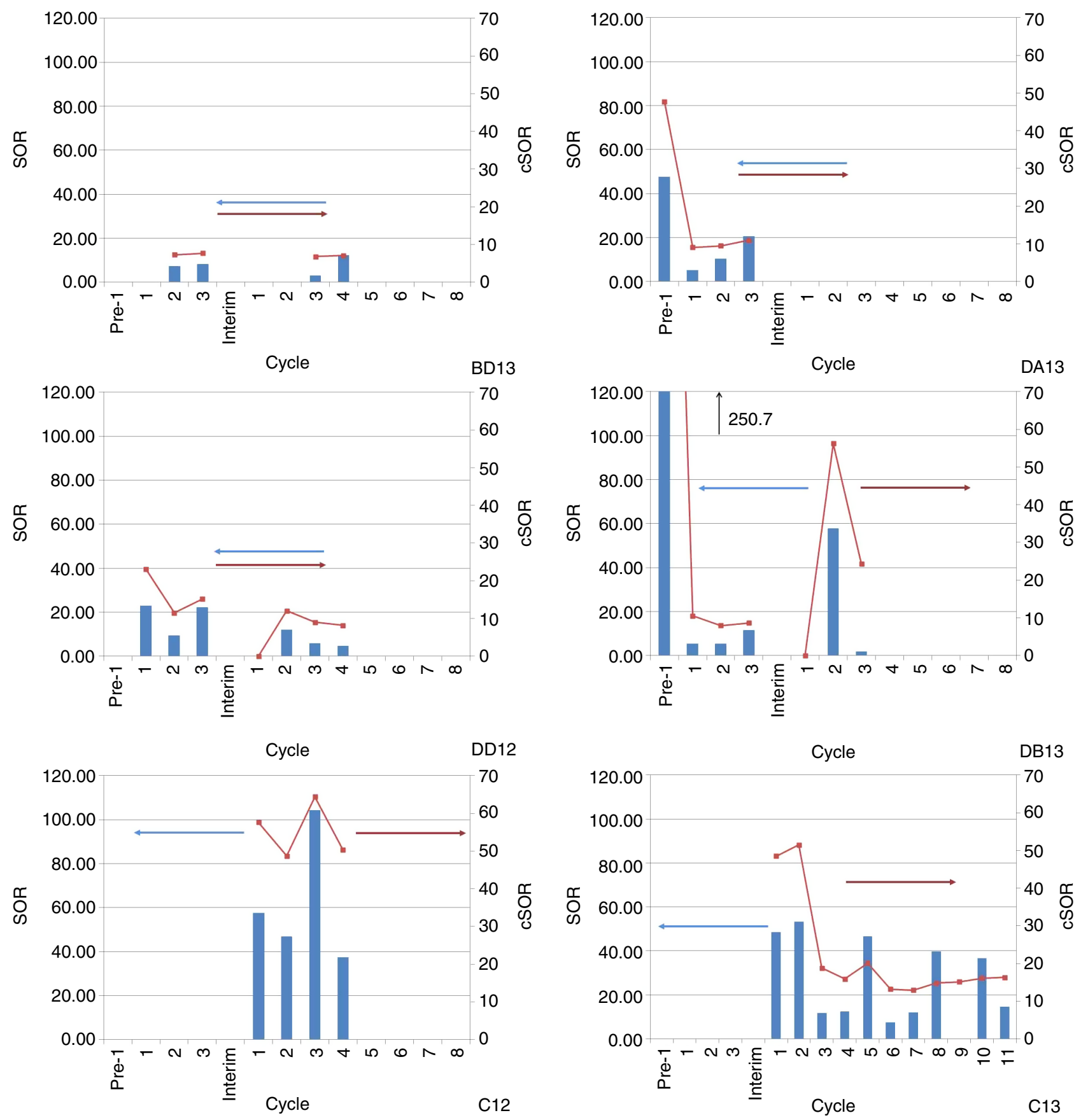

Figure 15

Cyclic and cumulative Steam Oil Ratio (SOR) for different McLean pilot CSS wells. Interim indicates McLean pattern expansion and Well C13 was operated as a single CSS pilot from Cycle 5.

SOR generally decreased with increase in the number of cycles. During operation of the original pattern, Well DB13 showed a rapid improvement in recovery performance; cSOR declined from about $250 \mathrm{~m}^{3} / \mathrm{m}^{3}$ to less than $20 \mathrm{~m}^{3} / \mathrm{m}^{3}$. Nevertheless, Well DB13 performed poorly during operation of the expanded 

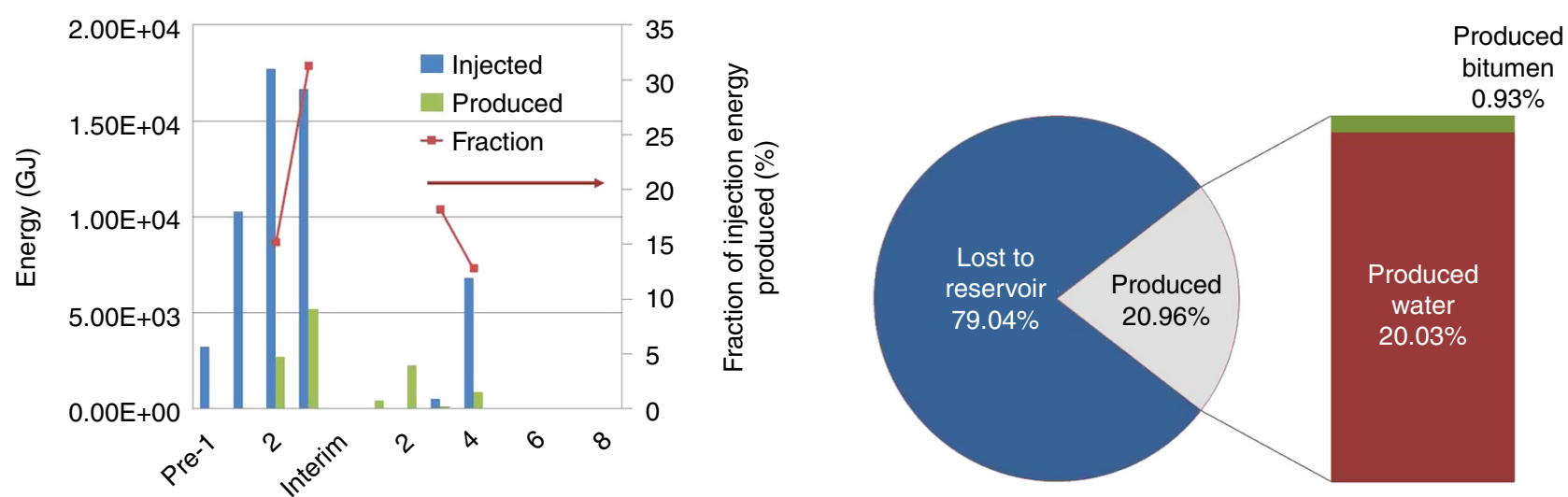

BD13

Cycle
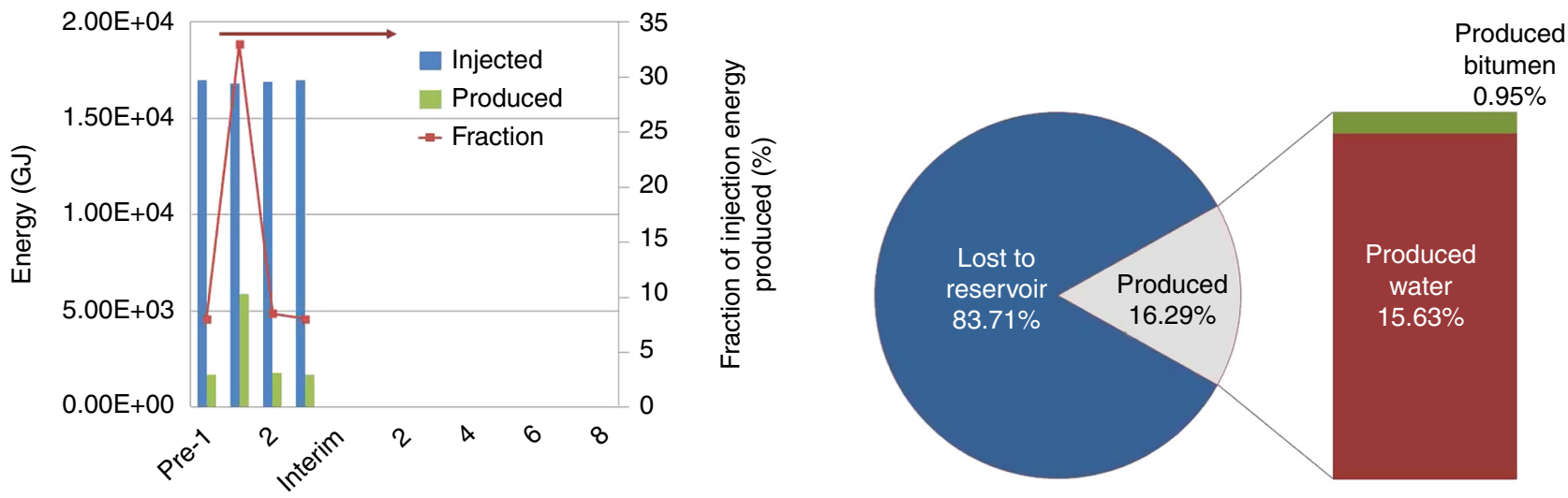

BA13

Cycle
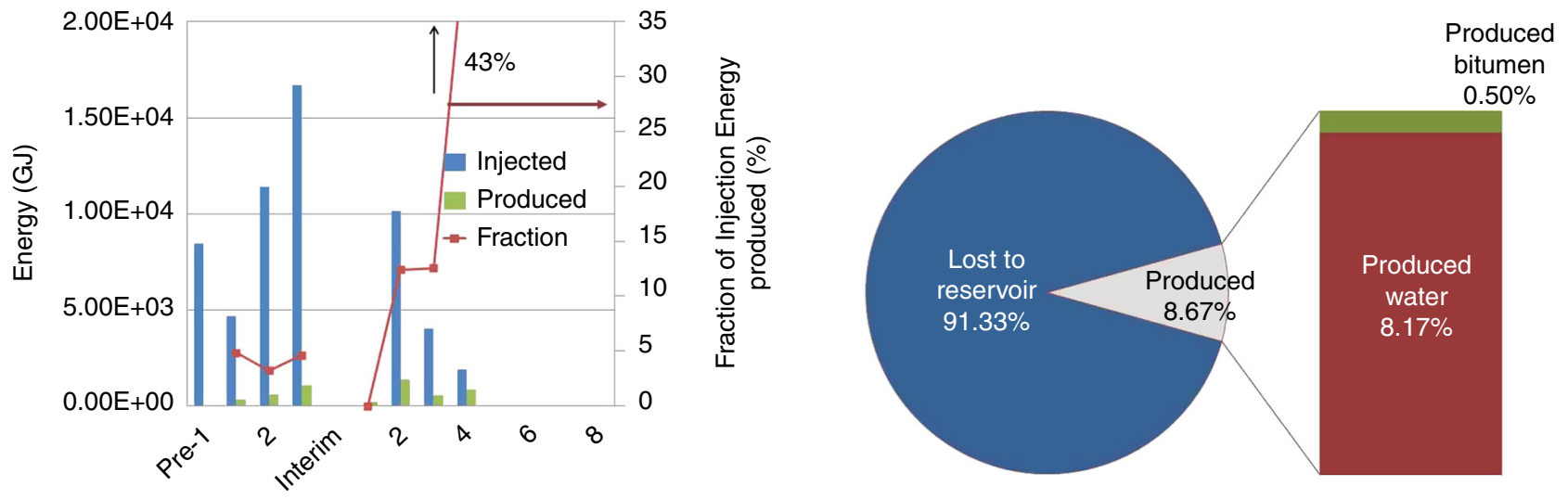

DD12

Cycle

Figure 16

Calculated energy balance for different McLean pilot CSS wells. Interim indicates McLean pattern expansion and Well C13 was operated as a single CSS pilot from Cycle 5 .

pattern, whereas Well BD13 showed consistently reasonable performance $\left(\mathrm{cSOR}<10 \mathrm{~m}^{3} / \mathrm{m}^{3}\right)$. It is therefore suspected that steam injected into Well DB13 mobilized bitumen in a network of vugs/karsts/fractures interconnected to Well BD13 and preferentially advanced towards Well BD13. The rapid improvement in recovery 

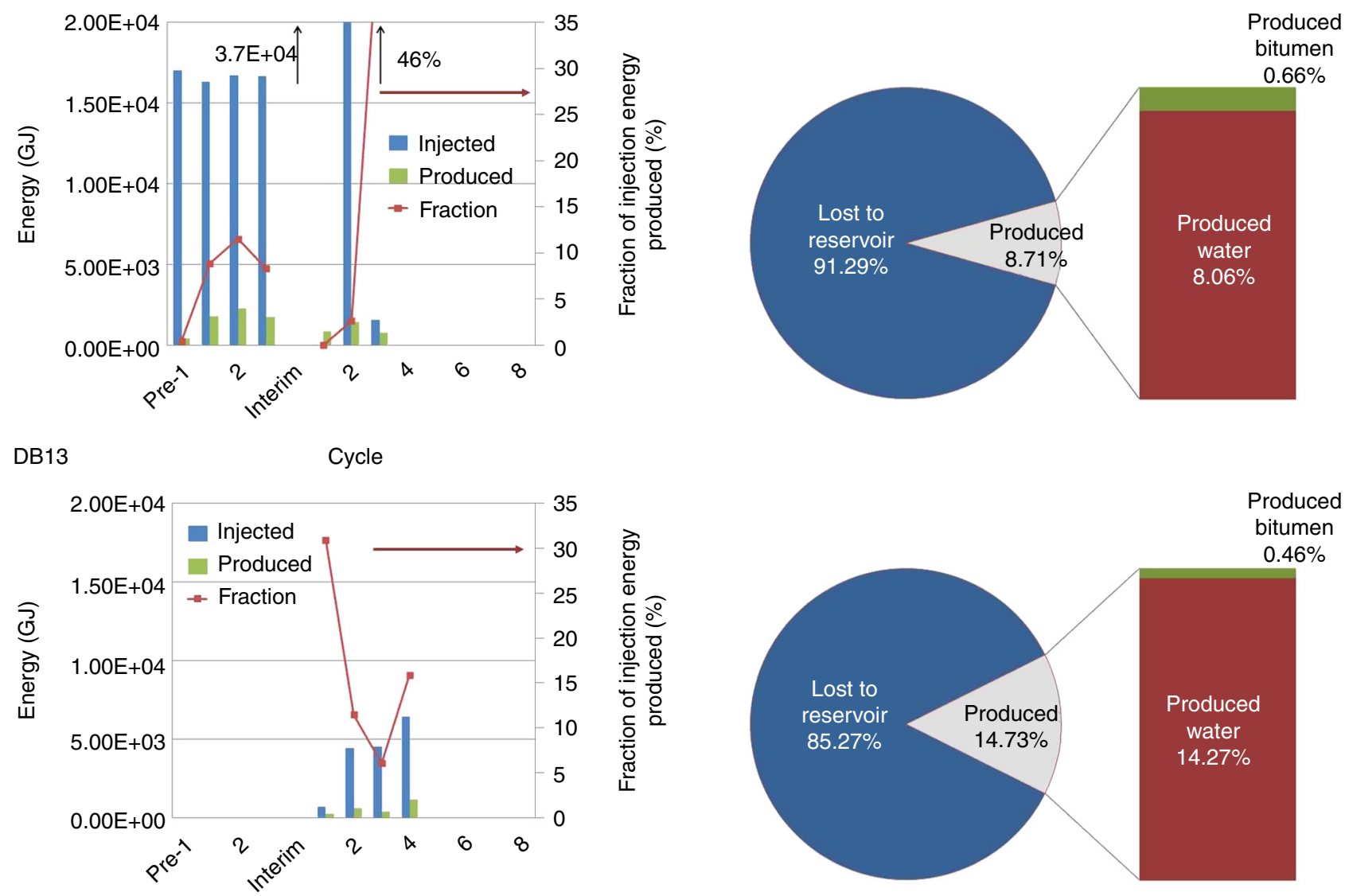

$\mathrm{C} 12$

Cycle
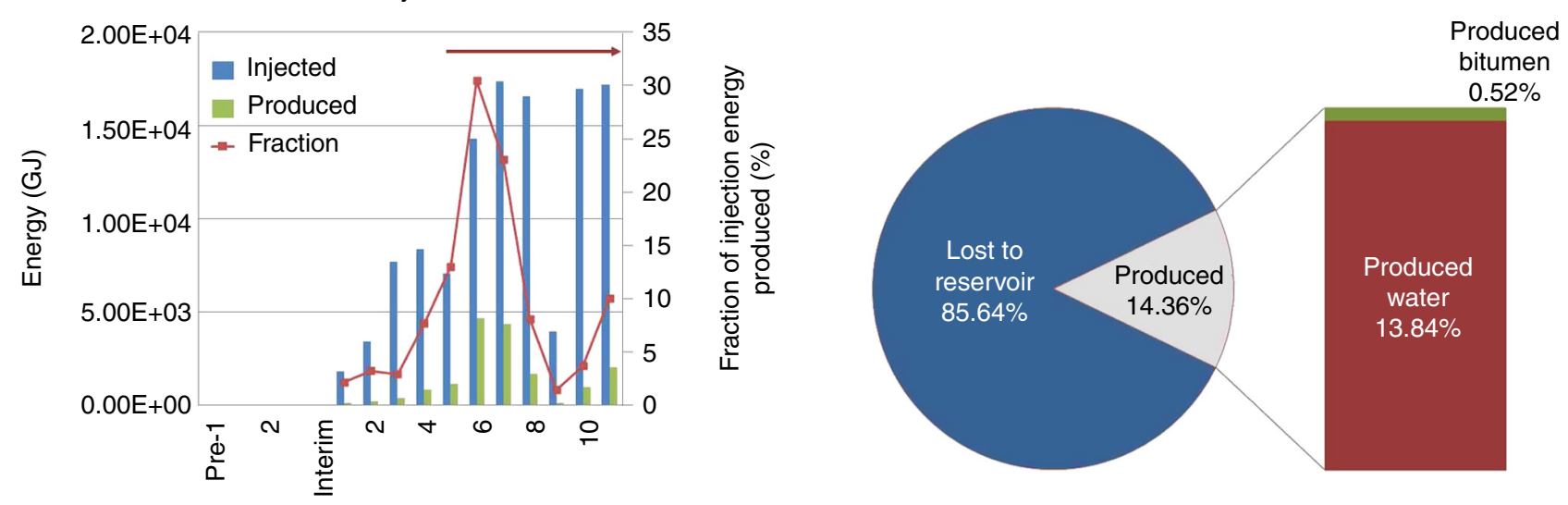

C13

Cycle

Figure 16

(continued)

performance of Well DB13 would have occurred prior to steam breakthrough, followed by a decline in performance as injected steam channeled into Well BD13. Analysis of the water balance for McLean indicates that excluding Well BD13, all other wells had a net water injection leading to overall $78 \%$ recovery of injected water. Therefore, interference from the aquifer zone during the pilot was unlikely. 

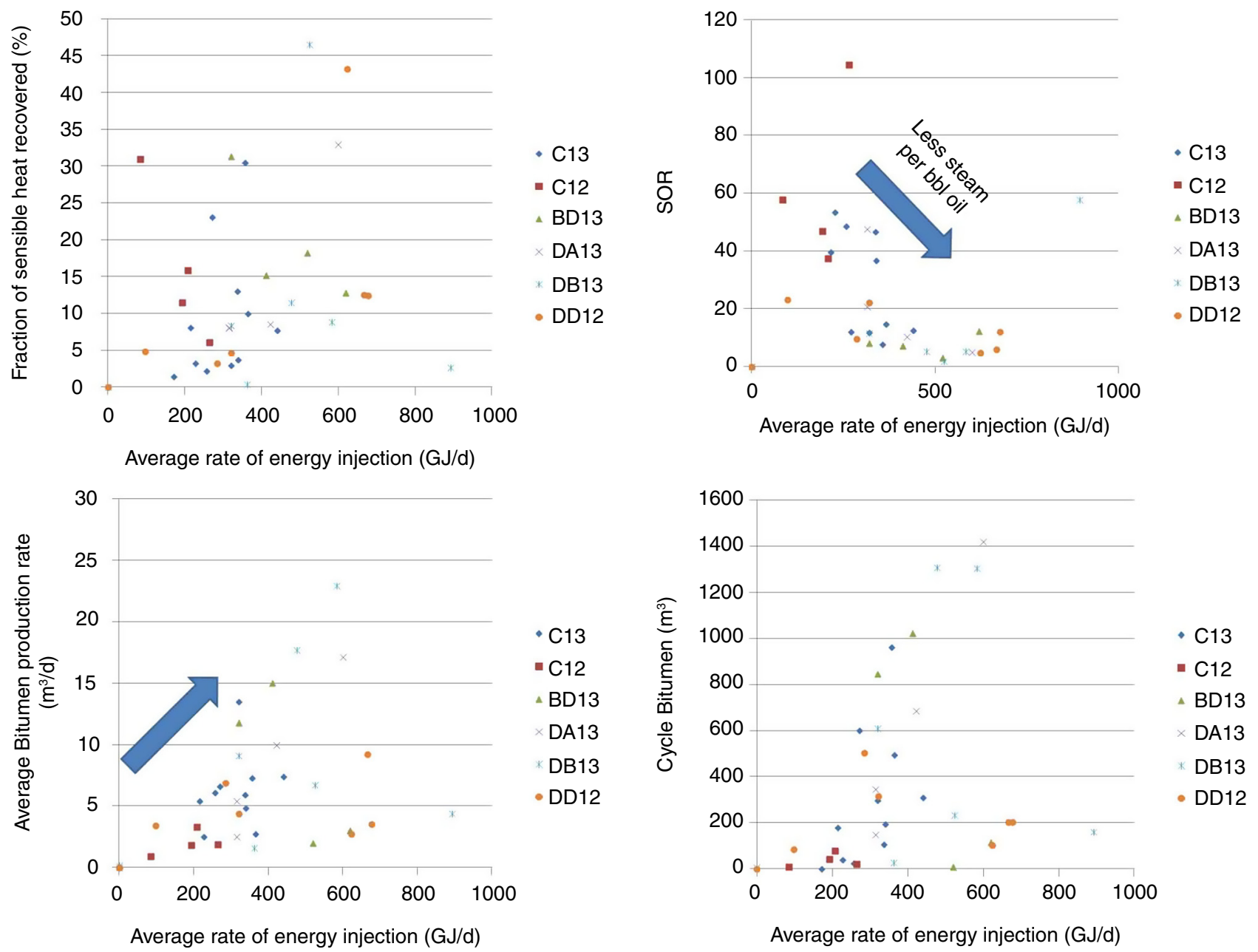

Figure 17

Effect of steam injection rate on performance indices for different McLean pilot CSS wells.

\subsection{Energy Balance Analysis}

Consistent with the approach described in the research scope and methods section above, energy balance calculations were performed for the McLean pilot. Figure 16 shows the results including cyclic injected and produced energy, fraction of injected energy recovered and distribution of energy in separate phases. Similar to earlier Grosmont pilots, the majority of injected energy $(>79 \%$ ) was retained in the reservoir. In addition, only a small fraction $(<1 \%)$ of produced energy was in the mobilized bitumen phase. Unlike the Buffalo Creek pilot, where the fraction of injected energy recovered increased with an increase in the number of steam cycles, the result of the McLean pilot does not show any trend. In addition to interference of steam conformance zones, the variability in calculated energy results was most likely influenced by operational issues associated with casing problems in some of the wells. The increased bitumen production after the Cycle 9 foam pilot test led to an increased fraction of recovered energy during this period, as illustrated in Figure 16. The effects of the average energy injection rate on the fraction of sensible heat recovered, SOR, bitumen production rate and cyclic produced bitumen volume are shown in Figure 17. The rate of energy injection is somewhat related to injection pressure in the sense that the energy injection rate was generally lower at higher injection pressures (i.e. lower injectivity). The SOR decreased with increase in the energy injection rate. This is related to high injectivity at lower pressures precluding displacement of bitumen too far away from the production well. Figure 17 also shows a positive correlation between the energy injection rate and bitumen production rate. In contrast, a large 


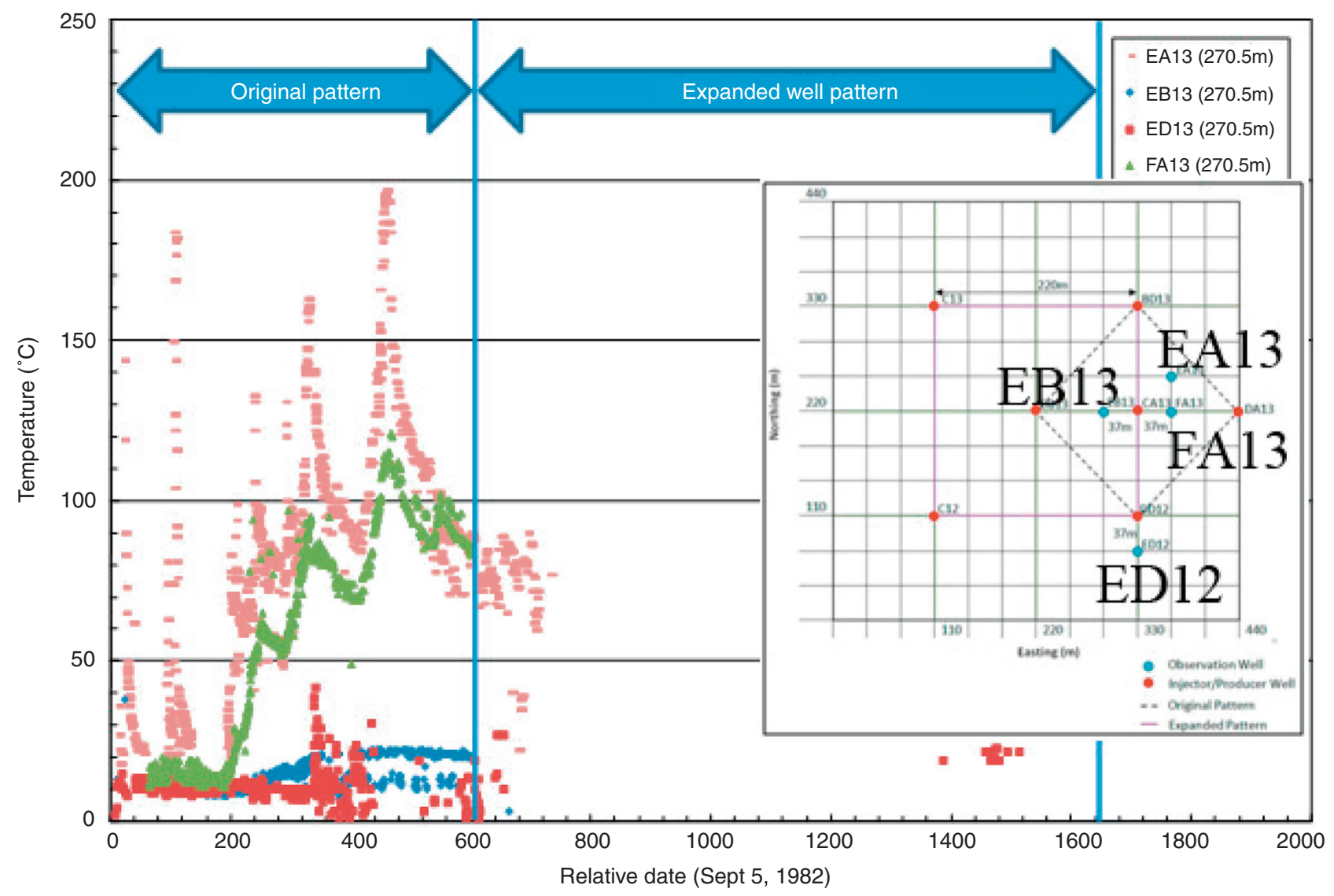

Figure 18

Temperature profile recorded in the observation wells (blue colored in inset pattern map) at the top of Grosmont Zone C ( $270 \mathrm{~m})$ during McLean CSS pilot tests.

amount of scatter existed for the produced bitumen volume and fraction of energy recovered, highlighting their poor correlation with the rate of energy injection. This indicates that although the bitumen production rate may increase with the rate of energy injection, this may not necessarily translate to a larger volume of produced bitumen, due primarily to rapid decline in the bitumen rate during the production cycle.

\subsection{Temperature Visualization}

One major design flaw of the McLean pilot was the absence of observation wells in strategic locations. Only four observation wells were available. Worse still, a change in operational method (from steamflood to CSS) occasioned by steam losses from Well CA-13 to the overlying reservoir (Zone D) made these observation wells less strategic. This unfortunately devalued the McLean pilot in terms of improved understanding of in situ distribution and directional flow of heat energy. Temperature data recorded at observation wells plotted against time are shown in Figure 18. It is possible that upward steam channeling still continued even after shut in of Well CA13. Along-well temperature profiles showed evidence of convective heating at the top of Zone C in wells EA13 and FA13 (temperatures exceeding $120^{\circ} \mathrm{C}$ ), while wells EB13 and ED12 did not show any hydraulic communication with injected steam (temperatures averaging $25^{\circ} \mathrm{C}$ ). Nevertheless, the heterogeneity of Grosmont carbonate even on a scale of less than $40 \mathrm{~m}$ is evident. The difficulties associated with interpreting the temperature data of the McLean pilot make it imperative that a carefully designed steam strategy must be associated with future pilots employing multiple CSS wells.

\section{DISCUSSION}

An extended analysis of early pilots in the Grosmont points towards an attractive potential for steam-based 
commercial development of this reservoir by currently available technology. In agreement with previous authors, these early pilots were generally successful. Previous analysis of these early Grosmont pilots (Yuan et al., 2010; Novak et al., 2007) identified a number of technology advancements as particularly relevant to the commercial development of Grosmont carbonate. These include; horizontal wells and advancement in completions, SAGD, solvent-assisted SAGD, 3D/4D seismic, VAPor EXtraction (VAPEX) and improved CSS. Following our integrated analysis, however, we identified specific adaptations of some of these reported technologies to the Grosmont. In particular, we propose the alignment of future horizontal wells along the NE direction (parallel to the direction of observed preferential steam channeling) to promote transverse flow of steam into lower permeability matrix objects in the Grosmont. Although SAGD has proved significantly successful in sandstone reservoirs of Athabasca and Cold Lake, we suspect, based on this pilot analysis, that continuous steam injection (associated with SAGD) will most likely result in excessive heat loss to 'steam sinks', leading to a poor SAGD performance in the Grosmont reservoir. In addition, although both cases of horizontal well CSS and SAGD benefit from gravity drainage, it is quite likely that mobilized bitumen at the edges of the SAGD steam zone may be trapped in low permeability paths and not reach the production well. A key attraction of the CSS process is that unlike SAGD, heated bitumen is produced via the same path that injected steam had traveled. In addition, the potential to expel matrix oil via steam flashing during CSS offers a realistic chance of improved recovery over SAGD. Of course, lower pressure CSS is desirable to mitigate instability of the steam zone. For these reasons, we therefore suggest the use of horizontal well CSS (instead of SAGD) as a more technically appropriate protocol for the Grosmont and similar bitumen carbonate reservoirs. This hypothesis is contrary to the assertion in favor of SAGD by previous authors (Yuan et al., 2010). However, the ongoing SAGD pilot at Grosmont (Saleski) will offer definitive field data on the performance of SAGD in the Grosmont while confirming the consistency or otherwise of our suspected challenges with the application of SAGD at Grosmont.

\section{SUMMARY AND CONCLUSIONS}

In summary, the integrated analysis of early Grosmont steam pilots presented here has revealed many positive insights that should help to improve the design of future pilots and commercial development of this massive bitumen deposit. In agreement with earlier discussions (Jiang et al., 2010; Yuan et al., 2010; Novak et al., 2007), these Grosmont steam pilots were considerably successful based on reservoir performance factors such as high injectivity, peak bitumen delivery rate of about $70 \mathrm{~m}^{3} / \mathrm{d}$ and a low cyclic steam-to-oil ratio of about $3.6 \mathrm{vol} / \mathrm{vol}$ (steam expressed as CWE). Considering the heterogeneous nature of the Grosmont Formation, it was not surprising that significant performance variation was exhibited by shortly spaced wells.

Operational factors such as poor steam quality, nonoptimized high injection pressures and completion issues appear to have heavily impacted recovery performances. As an example, the very low injection steam quality for the Chipewyan River pilot for highly viscous bitumen prevents effective assessment of reservoir effects.

Single-well CSS tests (Buffalo Creek Well 10A and McLean Well C13) performed much better than multiple-well tests. This is a tremendously positive driver as it points to the viability of development with sparsely spaced wells, thereby making Grosmont development economically attractive.

Spatial analysis showed that directional steam flow was predominantly towards the NE direction. For future CSS processes in the Grosmont Formation, we propose utilizing horizontal wells and aligning the horizontal length along the NE direction. This may encourage steam flow in the transverse direction, thereby reducing steam channeling and improving matrix recovery. Positive results obtained from the Grosmont foam pilot support the viability of this proposed improvement in process development.

\section{ACKNOWLEDGMENTS}

The authors acknowledge funding and data support from Laricina Energy Ltd. and funding from the Natural Sciences and Engineering Research Council (NSERC) (MSK, IDG).

\section{REFERENCES}

Ahmed K.N., Milhem M.M. (1989) Operation of a second steam stimulation pilot project in Kuwait, Middle East Oil Show, Bahrain, 11-14 March, SPE Paper 17987.

Babadagli T., Al-Bemani A. (2007) Investigation on matrix recovery during steam injection into heavy-oil containing carbonate rocks, J. Petrol. Sci. Eng. 58, 259-274.

Barrett K., Hopkins J., Wilde K.N., Connelly M.E. (2008) The origin of matrix and fracture mega-porosity in a carbonate bitumen reservoir, Grosmont Formation, Saleski, Alberta, 2nd World Heavy Oil Congress, Edmonton, Canada, 10-12 March, Paper 2008-344. 
Briggs P.J., Beck D.L., Black C.J.J., Bissell R. (1992) Heavy oil from fractured carbonate reservoirs, SPE Reserv. Eng. J. 7, 2, 173-179.

Brooks P.W., Fowler M.G., MacQueen R.W. (1988) Biomarker geochemistry of Cretaceous oilsands, heavy oils and Paleozoic carbonate trend bitumens, Western Canada basin, In: Meyer R.F., Wiggins E.J. (eds), 4th International UNITAR/UNDP Conference on Heavy Crude and Tar Sands, Vol. 2, geology, chemistry: International Conference on Heavy Crude and Tar Sands; pp. 594-606.

Brown J., Deemer A., Al-Dhafeeri F., Lekia S., Hoadley S., Al-Mutairi G., Al-Yami F., Barge D. (2011) Early results from a carbonate steamflood pilot in 1st Eocene reservoir, Wafra field, PZ, SPE Heavy Oil Conference and Exhibition, Kuwait City, Kuwait, 12-14 Dec, SPE Paper 150605.

Buschkuehle B.E., Hein F.J., Grobe M. (2007) An overview of the geology of the Upper Devonian Grosmont Carbonate Bitumen Deposit, Northern Alberta, Canada, Nat. Resour. Res. 16, 1, 3-15.

Chevron Canada Resources Limited (1983) Algar Thermal Recovery Project, Final Report.

Couderc B.M., Verpeaux J.F., Monfrin D., Quettler U.H. (1990) Emeraude vapeur: a steam pilot in an offshore environment, SPE Reservoir Eng. J. 5, 4, 508-516.

Dreher K.D., Kenyon D.E., Iwere F.O. (1986) Heat flow during steam injection into a fractured carbonate reservoir, Proceeding SPE Enhanced Oil Recovery Symposium, Tulsa, USA, SPE Paper 14902.

Edmunds N., Barret K., Solanki S., Cimolai M., Wong A. (2009) Prospects for commercial bitumen recovery from the Grosmont carbonate, Alberta, J. Can. Pet. Technol. 48, 9, 26-32. ERCB (2011) Energy Resources Conservation Board, Alberta's energy reserves 2010 and supply/demand outlook 2011-2020, ST98-2011, pp. 3-6.

Gates I.D. (2011) Basic Reservoir Engineering, 1st edn., Kendall-Hunt, Dubuque.

Harrison R.S., McIntyre B.G. (1981) The geologic setting of the Grosmont thermal recovery project, Northeastern Albert, Proceeding Alberta Oil Sands and Technology Research Authority (AOSTRA), Seminar on Advance in Petroleum Recovery and Upgrading Technology.

Hjelmeland O.S., Larrondo L.E. (1986) Experimental investigation of the effects of temperature, pressure, and crude oil composition on interfacial properties, SPE Reserv. Eng. 1, 4, 321-328.

Jiang Q., Yuan J., Russel-Houston J., Thornton B., Squires A. (2010) Evaluation of recovery technologies for the Grosmont carbonate reservoirs, J. Can. Pet. Technol. 49, 5, 56-64.

Luo P., Machel H.G. (1994) Petrophysical properties of matrix blocks of a heterogeneous dolostone reservoir - the upper Devonian Grosmont Formation, Alberta, Canada, Bull. Can. Petrol. Geol. 42, 465-481.

Luo P., Machel H.G. (1995) Pore size and pore throat types in a heterogeneous reservoir, Devonian Grosmont formation, Western Canada Sedimentary Basin, AAPG Bull. 79, 11, 1698-1720.

Luo P., Dembicki E.A., Huebscher H., Machel H.G. (1993) Diagenesis and reservoir characteristics of the heavy-oil carbonate trend in Western Canada - refined evaluation of reservoir characteristics of the Grosmont Formation, AOSTRA Report 7, p. 170.
Macaulay R.C., Krafft J.M., Hartemink M., Escovedo B. (1995) Design of a steam pilot in a fractured carbonate reservoir - Qarn Alam field, Oman, Internatioal Heavy Oil Symposium, Calgary, Canada, 19-21 June, SPE Paper 30300.

Machel H.G., Hawlader H. (1990) Diagenesis and reservoir characteristics of the heavy-oil carbonate trend in western Canada, preliminary investigations of facies, diagenesis, porosity, and bitumen saturation of the Grosmont Formation: AOSTRA, reports 2, p.169.

Milhem M.M., Ahmed K.N. (1987) Performance of a pilot cyclic steam stimulation project in Kuwait, Middle East Oil Show, Bahrain, 7-10 March, SPE Paper 15733.

Mollaei A., Maini B. (2010) Steam flooding of naturally fractured reservoirs: basic concepts and recovery mechanisms, $J$. Can. Pet. Technol. 49, 1, 65-70.

Nakamura S., Sarma H.K., Umucu T., Issever K., Kanemitsu M. (1995) A critical evaluation of a steamflood pilot in a deep heavy carbonate reservoir in Ikiztepe field, Turkey, $S P E$ Annual Technical Conference and Exhibition, Dallas, USA, 22-25 Oct., SPE paper 30727.

Novak J., Edmunds N., Cimolai M. (2007) A history match of CSS recovery in the Grosmont, 8th Canadian International Petroleum Conference, Calgary, Canada, 12-14 June, SPE Paper 2007-154.

Sahuquet B.C., Ferrier J.J. (1982) Steam-drive pilot in a fractured carbonated reservoir: Lacq Supérieur field, J. Petrol. Technol. 34, 4, 873-880.

Sahuquet B.C., Spreux A.M., Corre B., Guittard M.P. (1990) Steam injection in a low-permeability reservoir through a horizontal well in Lacq Supérieur field, SPE Annual Technical Conference and Exhibition, Louisiana, USA, 23-26 Sept, SPE Paper 20526.

Samir M. (2010) Rejuvenation Issaran field - success story, North Africa Technical Conference and Exhibition, Cairo, Egypt, 14-17 Feb., SPE Paper 127847.

Snell J.S., Close A.D. (1999) Yates field steam pilot applies latest seismic and logging monitoring techniques SPE Annual Technical Conference and Exhibition, Texas, USA, 3-6 Oct., SPE Paper 56791.

Theriault F. (1988) Lithofacies, diagenesis, and related reservoir properties of the Upper Devonian Grosmont Formation, Northern Alberta, Bull. Can. Petrol. Geol. 36, 1, 52-69.

Theriault F., Hutcheon I. (1987) Dolomitization and calcitization of the Devonian Grosmont Formation, Northern Alberta, J. Sediment. Res. 57, 6, 955-966.

Union Oil Company of Canada Limited (1975) UNOCAL, Progress Report Injectivity and Sample Recovery Test, Grosmont Formation - Chipewyan River Test Site.

Union Oil Company of Canada Limited (1977) UNOCAL, Progress Report Steam Stimulation and Communication Heating Test, Chipewyan River Test Site - Grosmont and Ireton Formations.

Union Oil Company of Canada Limited (1980) UNOCAL, Progress Report Steam Stimulation Buffalo Creek Test Site, ERCB Approval No. 2367C.

Union Oil Company of Canada Limited (1982-1983) UNOCAL, Progress Report McLean Heavy Oil Pilot, ERCB Approval No. 3603.

Walker D. (1986) Regional Stratigraphy of the Upper Devonian Grosmont Formation, Northern Alberta, AOSTRA/ARC Oil Sands Geology Agreement 158B, Open File Report-2, June. 
Yuan J.-Y., Jiang Q., Russel-Houston J., Thornton B., Putman P. (2010) Evolving recovery technologies directed towards commercial development of the Grosmont carbonate reservoirs, Canadian Unconventional Resources and International Petroleum Conference, Calgary, Canada, 19-21 Oct., SPE Paper 137941.

Zhao Y., Machel H. (2012) Viscosity and other rheological properties of bitumen from the upper devonian Grosmont reservoir, Alberta, Canada, AAPG Bull. 96, 1, 133-153.

Zhou Y., Lin Y., Liu L., Chen G. (1998) Steam pilot in the Cao-20 fracture limestone with extra heavy oil, 7th UNITAR Conference on Heavy Crude and Tar Sands, Beijing, China, 27-30 Oct., SPE Paper 1998-131.
Ziegler V.M. (1985) Chevron Algar 10, Simulation of Steam Injection at the House River Field, Alberta, Canada, Project 48,817, January.

Ziegler V.M., Bay A.R. (1984) Chevron Algar 9, Special Core Tests Well Chevron CCl - House 10-36-81-17W4 M, House River Field, Alberta, Canada, Project 48,991, January.

Manuscript accepted in January 2013 Published online in September 2013

Cite this article as: C.C. Ezeuko, J. Wang, M.S. Kallos and I.D. Gates (2013). Towards the Development of Bitumen Carbonates: An Integrated Analysis of Grosmont Steam Pilots, Oil Gas Sci. Technol 70, 6, 983-1005. 